\title{
Alleviating dormancy in Brassica oleracea seeds using NO and KAR1 with ethylene biosynthetic pathway, ROS and antioxidant enzymes modifications
}

Abdul Sami, Muhammad Waheed Riaz, Xiangyu Zhou, Zonghe Zhu and Kejin Zhou*

\begin{abstract}
Background: Seed dormancy is a prevailing condition in which seeds are unable to germinate, even under favorable environmental conditions. Harvested Brassica oleracea (Chinese cabbage) seeds are dormant and normally germinate (poorly) at $21^{\circ} \mathrm{C}$. This study investigated the connections between ethylene, nitric oxide (NO), and karrikin 1 (KAR1) in the dormancy release of secondary dormant Brassica oleracea seeds.

Results: NO and KAR1 were found to induce seed germination, and stimulated the production of ethylene and 1aminocyclopropane-1-carboxylic acid (ACC), and both ethylene biosynthesis enzyme ACC oxidase (ACO) [1] and ACC synthase (ACS) [2]. In the presence of NO and KAR1, ACS and ACO activity reached maximum levels after 36 and $48 \mathrm{~h}$, respectively. The inhibitor of ethylene 2,5-norbornadiene (NBD) had an adverse effect on Brassica oleracea seed germination (inhibiting nearly $50 \%$ of germination) in the presence of $\mathrm{NO}$ and KAR1. The benefits from NO and KAR1 in the germination of secondary dormant Brassica oleracea seeds were also associated with a marked increase in reactive oxygen species (ROS) $\left(\mathrm{H}_{2} \mathrm{O}_{2}\right.$ and $\left.\mathrm{O}_{2}{ }^{-}\right)$and antioxidant enzyme activity at early germination stages. Catalase (CAT) and glutathione reductase (GR) activity increased $2 \mathrm{~d}$ and $4 \mathrm{~d}$, respectively, after treatment, while no significant changes were observed in superoxide dismutase (SOD) activity under NO and KAR1 applications. An increase in $\mathrm{H}_{2} \mathrm{O}_{2}$ and $\mathrm{O}_{2} \cdot{ }^{-}$levels were observed during the entire incubation period, which increasing ethylene production in the presence of $\mathrm{NO}$ and KAR1. Abscisic acid (ABA) contents decreased and glutathione reductase (GA) contents increased in the presence of NO and KAR1. Gene expression studies were carried out with seven ethylene biosynthesis ACC synthases (ACS) genes, two ethylene receptors (ETR) genes and one ACO gene. Our results provide more evidence for the involvement of ethylene in inducing seed germination in the presence of NO and KAR1. Three out of seven ethylene biosynthesis genes (BOACS7, BOACS9 and BOACS11), two ethylene receptors (BOETR1 and BOETR2) and one ACO gene (BOACO1) were up-regulated in the presence of $\mathrm{NO}$ and KAR1.

Conclusion: Consequently, ACS activity, ACO activity and the expression of different ethylene related genes increased, modified the ROS level, antioxidant enzyme activity, and ethylene biosynthesis pathway and successfully removed (nearly 98\%) of the seed dormancy of secondary dormant Brassica olereace seeds after 7 days of NO and KAR1 application.
\end{abstract}

Keywords: Brassica oleracea, KAR1, Nitric oxide, Ethylene, Seed dormancy, Seed germination, ROS, Antioxidant enzymes

\footnotetext{
* Correspondence: zhoukejin@163.com

College of Agronomy, Anhui Agricultural University, Hefei 230036, China
}

(c) The Author(s). 2019 Open Access This article is distributed under the terms of the Creative Commons Attribution 4.0 International License (http://creativecommons.org/licenses/by/4.0/), which permits unrestricted use, distribution, and reproduction in any medium, provided you give appropriate credit to the original author(s) and the source, provide a link to the Creative Commons license, and indicate if changes were made. The Creative Commons Public Domain Dedication waiver (http://creativecommons.org/publicdomain/zero/1.0/) applies to the data made available in this article, unless otherwise stated. 


\section{Background}

Seed dormancy is a prevailing condition in which seeds are unable to germinate even in a favorable environment [1]. Seed dormancy can be divided into two types: [1] primary dormancy and [2] secondary dormancy. Primary dormancy is caused by the interaction between environmental factors and abscisic acid (ABA) in the late stages of seed development, while secondary dormancy is induced at different development stages and is caused by abiotic stresses including anoxia, temperature, and light [2]. Oxygen deficiency can increase the intensity of secondary dormancy [2]. Many phytohormones such as cytokinins, brassinosteroids, nitric oxide, and ethylene can play crucial roles in the alleviation of seed dormancy and germination $[3,4]$. The germination of dormant seeds of different plant species can also be regulated by a plant-derived smoke compound called karrikin-1 (KAR1) or butenolide [5]. It has been hypothesized that karrikins are a family of different isoforms. Six isoforms (KAR1 to KAR6) in the KARs group and others in smoke [6] have been identified, and these endogenous compounds are considered as the plant's hormones [7].

$\mathrm{NO}$ is a signaling molecule that associates with plant hormones to break seed dormancy [8]. During seed germination, the post-translational modifications of NOdependent proteins are key mechanisms [9]. Acidified $\mathrm{KNO}_{2}, S$-nitroso-N-acetylpenicillamine (SNAP), and $S$ nitrosoglutathione (GSNO) are the main donors of $\mathrm{NO}$ that help to release the dormancy conditions of seeds in different plant species, such as lettuce, redroot pigweed, barleyand apple [10-13]. Previous studies have shown that apple seed dormancy release can be achieved in the presence of the interaction between nitric oxide and ethylene biosynthesis $[8,13,14]$.

The phytohormone known as ethylene is involved in many important mechanisms in plants, such as ripening and reacting to various stresses [15-17]. It also has a pivotal role in the control of early germination and the alleviation of seed dormancy [18]. S-adenosylmethionine produces ethylene in seeds in two steps: [1] conversion of 1-aminocyclopropane-1-carboxylic acid (ACC) in the presence of ACC synthase (ACS); and [2] the oxidation of ACC $[17,19]$, which is the same pathway that was discovered from other plant parts. ACC synthase is considered an essential enzyme for ethylene production, while ACO is an enzyme that controls ethylene evolution to break seed dormancy [20]. In different plant species, ACS and ACO are two families and both contain multiple genes [21]. The members of these families regulate the transition from seed dormancy to nondormancy [22]. Under cold stress, all AtACO genes and two ACS genes (AtACS2 and AtACS11) were downregulated in A. thaliana [23-25], and FSACO1 transcript levels had been up-regulated to break seed dormancy in
Fagus sylvatica [26]. In wheat grains, the expressions level of some TaACOs genes increase after ripening [27].

Reactive oxygen species (ROS) and reactive nitrogen species, such as hydroxyl radical $\left({ }^{\circ} \mathrm{OH}\right)$, hydrogen peroxide $\left(\mathrm{H}_{2} \mathrm{O}_{2}\right)$, superoxide anion $\left(\mathrm{O}_{2}{ }^{\cdot-}\right)$, hydroxylamines, and nitrates are involved in the alleviation of seed dormancy in a number of plant species [28-30]. Seed germination usually starts when the level of reactive nitrogen species or reactive oxygen species reaches a certain level [31]. ROS accumulation releases sunflower seed dormancy [32]. Appropriate levels of ROS strongly correlate with the concentration and enzymatic activity of its compounds, such as catalase (CAT), glutathione reductase (GR), superoxide dismutase (SOD), mono-dehydro-ascorbate reductase (MDHAR), and peroxidases, as well as non-enzymatic compound such as ascorbate [29-32]. In monocotyledonous and dicotyledonous species, $\mathrm{H}_{2} \mathrm{O}_{2}$ has been considered the essential ROS in releasing seed dormancy [33]. Superoxide is converted into hydrogen peroxide in the presence of SOD after the conversion CAT starts its process and breaks $\mathrm{H}_{2} \mathrm{O}_{2}$ into oxygen and water, and these two enzymatic antioxidants SOD and CAT also cooperate with the ascorbate-glutathione cycle, dehydroascorbate reductase (DHAR), ascorbate peroxidase (APX) and glutathione reductase (GR) [34, 35]. Earlier studies explored that, sensitivity and balance between GA and ABA are causes of seed dormancy regulation [36]. The ABA is a key hormone in seeds and it is also responsible to maintain the seed dormancy, so decrease in ABA level reduces the seed dormancy [37]. GA is also considered as important hormone and helpful to release seed dormancy. In number of plant, GA can regulate seed germination and decreases dormancy while ABA regulates seed dormancy [38].

Previous data have shown that after harvest, Brassica oleracea (Chinese cabbage) seeds exhibit dormancy during a certain period of time [39]. Brassica species have no or little primary dormancy because primary dormancy usually establish in wild plants [39]. However, under environmental stress, secondary dormancy can be induced in Brassica cultivars [39]. In rapeseed, some abiotic factors such as changes in temperature, light intensity, humidity, and air pressure can have an effect on seed dormancy and germination [40]. Successful breakage of Brassica seed dormancy has been recorded under particular conditions such as light/dark regimes; alternating day/night temperatures; and $\mathrm{HCN}, \mathrm{NaClO}, \mathrm{NO}$ and ethylene interactions [41-43]. Therefore the aim of this study was to examine whether germination induction of dormant Brassica oleracea seeds by NO and KAR1 is associated with ethylene modification, control of $\operatorname{ROS}\left(\mathrm{H}_{2} \mathrm{O}_{2}\right.$ and $\left.\mathrm{O}_{2}{ }^{\cdot-}\right)$, and the enzymatic antioxidants activity. 


\section{Results}

\section{Effects of NO and KAR1 on germination}

NO $(5 \mathrm{mM})$ and KAR1 $\left(3 \times 10^{-9} \mathrm{M}\right)$ are very effective in breaking seed dormancy and increasing seed germination. Secondary dormant Brassica oleracea L. seeds were treated with NO $(5 \mathrm{mM})$ and KAR1 $\left(3 \times 10^{-9} \mathrm{M}\right)$. Under favorable conditions, non-treated secondary dormant Brassica oleracea seeds were unable to germinate, and after 3 days of sowing only $9 \%$ germination was noted at $21^{\circ} \mathrm{C}$, as shown in Fig. 1a. However, under nitric oxide and KAR1 treatments, the germination rate was enhanced after $48 \mathrm{~h}$. The germination rate increased even more after 4 and 5 days of nitric oxide and KAR1 applications. The germination rate actually correlated quite well with the treatment time; nearly all seeds were able to germinate as the treatment time increased. We observed that the effects of nitric oxide and karrikin1 were dependent on the duration of treatment.

In order to check the efficiency of NO and KAR1 on water uptake ability, secondary dormant Brassica oleracea seeds were incubated in water. The water contents of NO and KAR1-treated seeds were recorded at 5, 10, 20, 30, 40 and $50 \mathrm{~h}$. Brassica oleracea seeds treated with NO or KAR1 showed a rapid increase in water uptake, reaching 28-35\% after the initial $20 \mathrm{~h}$ of incubation (Fig. 1b). After $30 \mathrm{~h}$ of KAR1 and NO treatments, 38-40\% water uptake was observed. Furthermore, after $40 \mathrm{~h}$ of imbibition in KAR1 and $\mathrm{NO}$, water uptake increased to about $42-45 \%$ and continued to increase slightly until the end of incubation at $50 \mathrm{~h}$.

\section{Hydrogen peroxide and superoxide anion accumulation} As mentioned above, the increase in reactive oxygen species and enzymatic activities to certain levels can alleviate seed dormancy. Because of these results, we also measured $\mathrm{H}_{2} \mathrm{O}_{2}$ and superoxide anion concentrations in treated and non-treated samples. $\mathrm{H}_{2} \mathrm{O}_{2}$ concentration was measured after $1,2,3$ and $4 \mathrm{~d}$ of treatments with $\mathrm{NO}(5 \mathrm{mM})$ and KAR1 $\left(3 \times 10^{-9} \mathrm{M}\right)$. A rapid increase in $\mathrm{H}_{2} \mathrm{O}_{2}$ concentration was observed during $\mathrm{NO}$ and KAR1 treatment after 1, 2, 3 and $4 \mathrm{~d}$ (Fig. 2a), and the level of $\mathrm{H}_{2} \mathrm{O}_{2}$ was lower in control samples than in treated. $\mathrm{H}_{2} \mathrm{O}_{2}$ concentration was $6.5 \mu \mathrm{mol} \mathrm{g}{ }^{-1} \mathrm{FW}$ in control samples after $1 \mathrm{~d}$ of imbibition in water, and increased more than twofold under NO or KAR1 treatments. $\mathrm{H}_{2} \mathrm{O}_{2}$ concentration after 1 day was recorded as $6.5\left(\mu \mathrm{mol}-\mathrm{g}^{-1} \mathrm{FW}\right)$ in control samples, 15 ( $\mu \mathrm{mol}$ $\left.\mathrm{g}^{-1} \mathrm{FW}\right)$ in $\mathrm{NO}$, and $17\left(\mu \mathrm{mol}-\mathrm{g}^{-1} \mathrm{FW}\right)$ in KAR1 treated samples. $\mathrm{H}_{2} \mathrm{O}_{2}$ concentration after $2 \mathrm{~d}$ rapidly increased to $57\left(\mu \mathrm{mol}-\mathrm{g}^{-1} \mathrm{FW}\right)$ and $46\left(\mu \mathrm{mol}-\mathrm{g}^{-1} \mathrm{FW}\right)$ under $\mathrm{NO}$ and KAR1 treatments, respectively. After $3 \mathrm{~d}$ of treatment, concentration was $65\left(\mu \mathrm{mol}-\mathrm{g}^{-1} \mathrm{FW}\right)$ in control samples, $80\left(\mu \mathrm{mol}-\mathrm{g}^{-1} \mathrm{FW}\right)$ in NO treated samples and $78\left(\mu \mathrm{mol}-\mathrm{g}^{-1} \mathrm{FW}\right)$ in KAR1 treated samples. The maximum $\mathrm{H}_{2} \mathrm{O}_{2}$ concentration was noted at the end of $4 \mathrm{~d}$ under $\mathrm{NO}$ and KAR1 treatments. After $4 \mathrm{~d}$ of treatment, concentration was $74\left(\mu \mathrm{mol}-\mathrm{g}^{-1} \mathrm{FW}\right)$ in control samples, $85\left(\mu \mathrm{mol}-\mathrm{g}^{-1} \mathrm{FW}\right)$ in NO treated samples and 82 ( $\mu \mathrm{mol}-$ $\left.\mathrm{g}^{-1} \mathrm{FW}\right)$ in KAR1 treated samples.

Superoxide anion concentration was lower in nontreated samples after $1,2,3$ and $4 \mathrm{~d}$ of imbibition in water. In the presence of KAR1, we recorded a considerable increase in superoxide accumulation, while samples treated with NO had a lower stimulatory effect than KAR1 after $1 \mathrm{~d}$ (Fig. 2b). The superoxide anion level increased rapidly after 2,3 , and 4 d of incubation in $\mathrm{NO}$

\section{Effect of NO and KAR1 on germination}
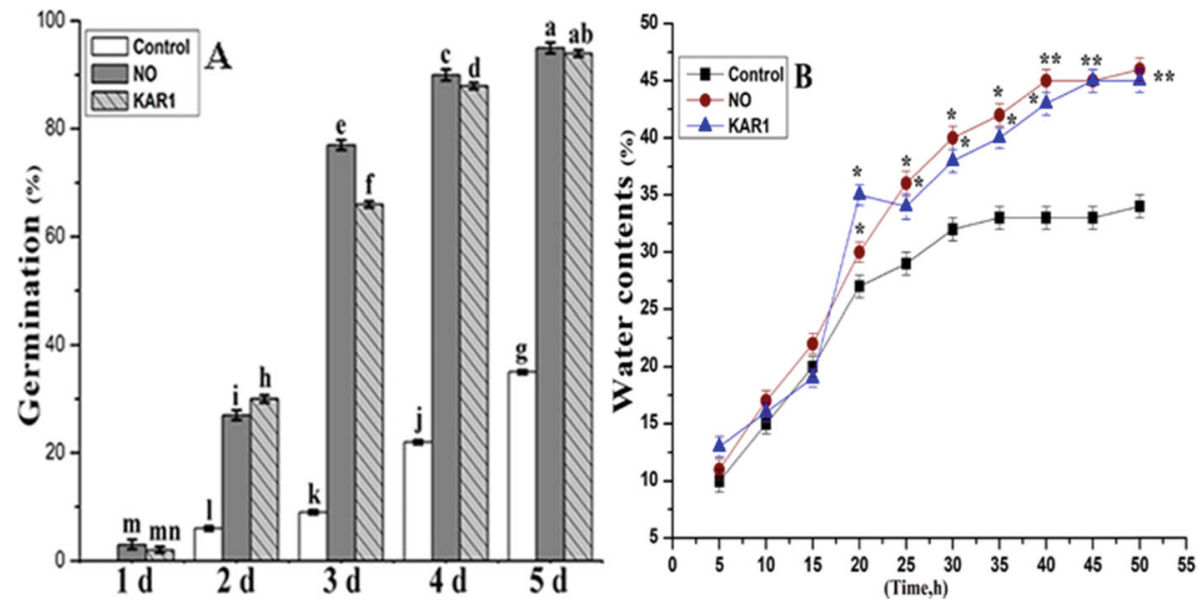

Fig. 1 Effects of $\mathrm{NO}(5 \mathrm{mM})$ and KAR1 $\left(3 \times 10^{-9} \mathrm{M}\right)$ on (a) Seed germination rate, $\mathbf{b}$ water contents in secondary dormant Brassica oleracea seeds during imbibition at $21{ }^{\circ} \mathrm{C}(n=3)$. Values are mean \pm SE. Significant differences between treatments determined by two-way analysis of variance (ANOVA), followed by HSD Tukey's test. Means with different letters are significantly different at $p<0.05$ and $P \leq 0.01$. KAR1, karrikin1; NO, Nitric oxide; h, hours 


\section{$\mathrm{H}_{2} \mathrm{O}_{2}$ accumulation and Superoxide anion accumulation}
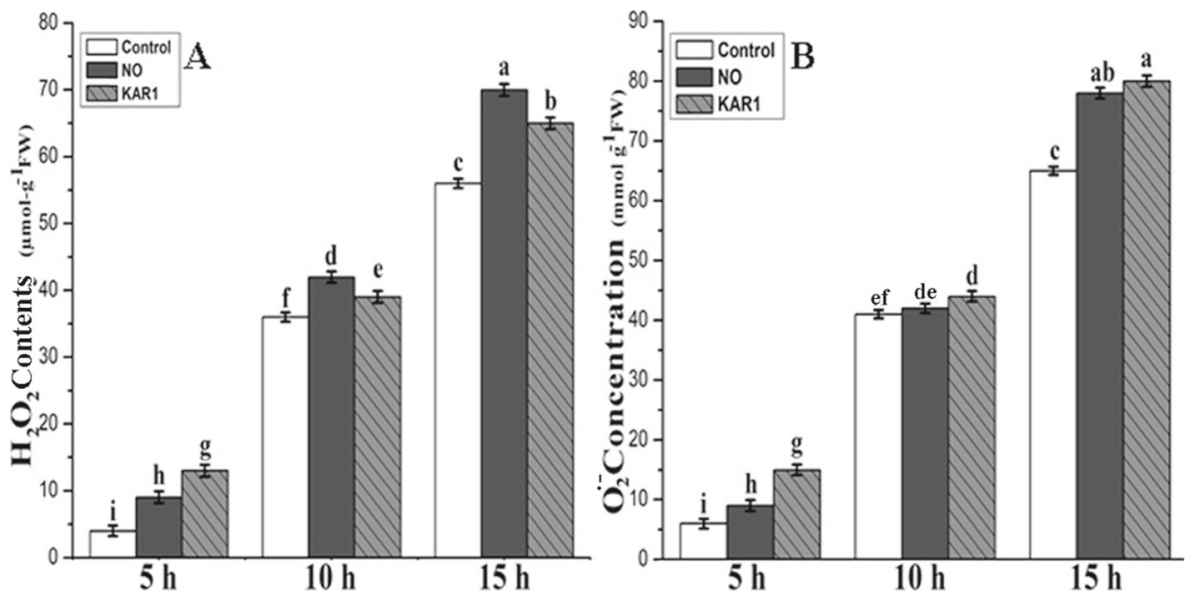

Fig. 2 Effects of $\mathrm{NO}(5 \mathrm{mM})$ and $\mathrm{KAR} 1\left(3 \times 10^{-9} \mathrm{M}\right)$ on $(\mathbf{a}) \mathrm{H}_{2} \mathrm{O}_{2}, \mathbf{b} \mathrm{O}_{2}{ }^{-}$in secondary dormant Brassica oleracea seeds during imbibition at $21^{\circ} \mathrm{C}$ $(n=3)$. Values are mean \pm SE. Significant differences between treatments determined by two-way analysis of variance (ANOVA), followed by HSD Tukey's test. Means with different letters are significantly different at $p<0.05$. KAR1, karrikin1; NO, Nitric oxide; $\mathrm{H}_{2} \mathrm{O}_{2}$, hydrogen peroxide; $\mathrm{O}_{2}{ }^{-}$ Superoxide anion, h, hours

or KAR1 solutions (Fig. 2b). The superoxide anion level in control samples after $1 \mathrm{~d}$ was $16\left(\mu \mathrm{mol}-\mathrm{g}^{-1} \mathrm{FW}\right), 19$ $\left(\mu \mathrm{mol}-\mathrm{g}^{-1} \mathrm{FW}\right)$ in NO samples, and $18\left(\mu \mathrm{mol}-\mathrm{g}^{-1} \mathrm{FW}\right)$ in KAR1 treated samples. The superoxide anion level after $2 \mathrm{~d}$ increased up to 51 ( $\mu$ mol- $\mathrm{g}^{-1} \mathrm{FW}$ ) in control samples, $55\left(\mu \mathrm{mol}-\mathrm{g}^{-1} \mathrm{FW}\right)$ under $\mathrm{NO}$, and $58\left(\mu \mathrm{mol}-\mathrm{g}^{-1} \mathrm{FW}\right)$ under KAR1 treatments. Moreover, after $3 \mathrm{~d}$ of treatments, the superoxide anion level was recorded as 75 $\left(\mu \mathrm{mol}-\mathrm{g}^{-1} \mathrm{FW}\right)$ in control samples, $81\left(\mu \mathrm{mol}-\mathrm{g}^{-1} \mathrm{FW}\right)$ in $\mathrm{NO}$, and $84\left(\mu \mathrm{mol}-\mathrm{g}^{-1} \mathrm{FW}\right)$ in KAR1 treated samples. After $4 \mathrm{~d}$ of treatments, the superoxide anion level had increased to $79\left(\mu \mathrm{mol}-\mathrm{g}^{-1} \mathrm{FW}\right)$ in control samples, 86 $\left(\mu \mathrm{mol}-\mathrm{g}^{-1} \mathrm{FW}\right)$ in $\mathrm{NO}$, and $88\left(\mu \mathrm{mol}-\mathrm{g}^{-1} \mathrm{FW}\right)$ in KAR1 treated samples.

\section{The activities of SOD, CAT and GR}

An imbalance among enzymatic activities can also cause seed dormancy. Secondary dormant Brassica oleracea seeds were treated with $\mathrm{NO}(5 \mathrm{mM})$ and KAR1 $\left(3 \times 10^{-}\right.$ ${ }^{9} \mathrm{M}$ ) for 1, 2, 3 and $4 \mathrm{~d}$, and SOD, CAT and GR activities were measured. The highest SOD activity was recorded in control Brassica oleracea embryos after $1 \mathrm{~d}(11 \mathrm{U}$ $\mathrm{min}^{-1} \mathrm{mg}^{-1}$ proteins) and $2 \mathrm{~d}\left(13 \mathrm{U} \mathrm{min}^{-1} \mathrm{mg}^{-1}\right.$ proteins), and2-3 times was higher and significantly different than treated samples (Fig. 3a). These results confirm the differences in SOD activity between treated and non-treated embryos, and how the SOD level gradually reduced after 3 and $4 \mathrm{~d}$. No significant difference was observed between control, NO and KAR1 treatments after $4 \mathrm{~d}$ of treatments. Overall, SOD activity decreased as the time of treatments increased. SOD activity was lower in samples under NO or KAR1 treatments than the control samples after 1, 2, 3 and $4 \mathrm{~d}$. In addition, SOD activity after $2 \mathrm{~d}$ of $\mathrm{NO}$ application was comparatively higher than KAR1 treated samples.

The catalase activity in Brassica oleracea embryos during the whole experiment stayed on a steady level in control samples; however, after $2 \mathrm{~d}$ of imbibition in water, the values decreased (Fig. 3b). NO and KAR1treated embryos exhibited a slight increase in CAT activity after 2 and $4 \mathrm{~d}$. Under KAR1 treatment, CAT activity was at a maximum (19 $\mathrm{U} \mathrm{min}^{-1} \mathrm{mg}^{-1}$ proteins) after $2 \mathrm{~d}$; under NO treatment, the maximum value was 18 (U $\mathrm{min}^{-1} \mathrm{mg}^{-1}$ proteins) after $4 \mathrm{~d}$ of treatment; and in control samples, the maximum CAT value $\left(15 \mathrm{U} \mathrm{min}^{-1} \mathrm{mg}^{-}\right.$ ${ }^{1}$ proteins) was recorded after $3 \mathrm{~d}$.

The lowest GR activity was recorded in the control samples. The GR activity increased to 3.3 (nmol GSSG $\mathrm{min}^{-1} \mathrm{mg}^{-1}$ proteins) in control samples after 2 and $3 \mathrm{~d}$, but after $4 \mathrm{~d}$, the GR activity went back to its initial rate (Fig. 3c). Meanwhile, in treated embryos, the GR activity increased continuously during germination with $\mathrm{NO}$ treatment, and GR values increased about three times and were significantly different than the control embryos after 4 days of imbibition (Fig. 3c). The maximum GR value 8 (mol GSSG $\mathrm{min}^{-1} \mathrm{mg}^{-1}$ proteins) was recorded after $4 \mathrm{~d}$ under NO treatment; under KAR1 treatment, the maximum value 7 ( $\mathrm{mol} \mathrm{GSSG} \mathrm{min}^{-1} \mathrm{mg}^{-1}$ proteins) was measured after $3 \mathrm{~d}$ of treatment.

\section{The effect of KAR1 and NO on the contents of ABA and GA}

Balance between $\mathrm{ABA}$ and $\mathrm{GA}$ are responsible for the regulation of the dormancy state and germination. NO 


\section{SOD, CAT and GR activities}
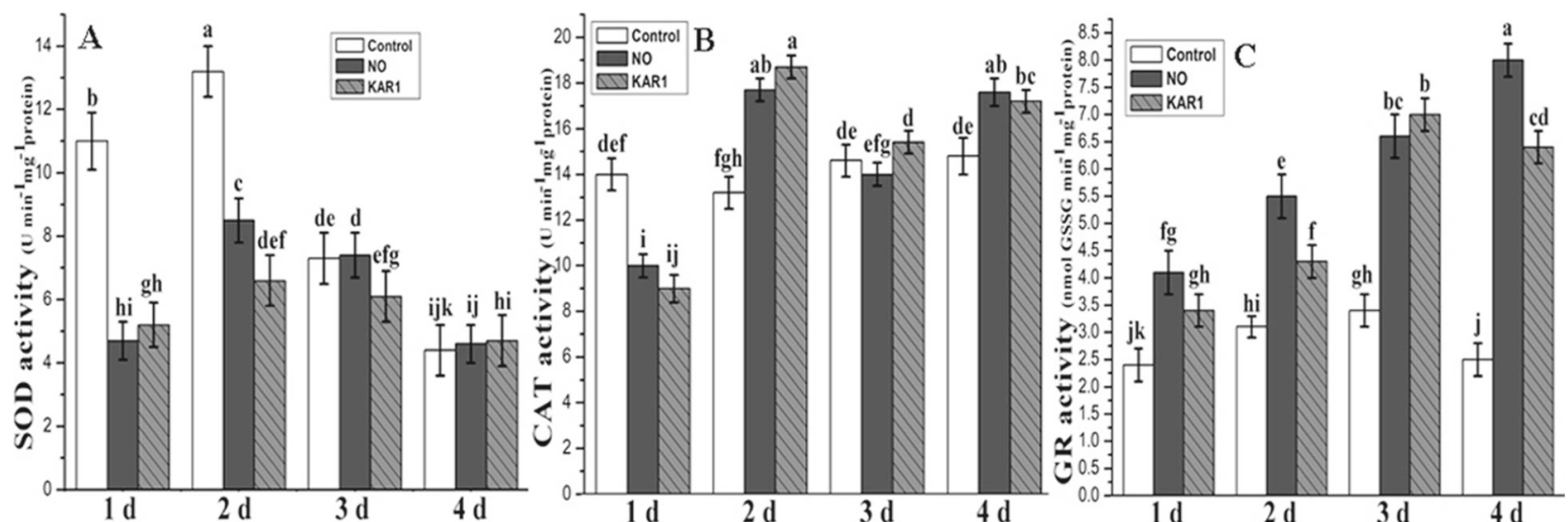

Fig. 3 Effects of $\mathrm{NO}(5 \mathrm{mM})$ and KAR1 $\left(3 \times 10^{-9} \mathrm{M}\right)$ on (a) SOD, b CAT, c GR in secondary dormant Brassica oleracea seeds during imbibition at $21^{\circ} \mathrm{C}(n=3)$. Values are mean \pm SE. Significant differences between treatments determined by two-way analysis of variance (ANOVA), followed by HSD Tukey's test. Means with different letters are significantly different at $p<0.05$. KAR1, karrikin1; NO, Nitric oxide; SOD, Superoxide dismutase; CAT, Catalase; GR, Glutathione reductase; d, days

$(5 \mathrm{mM})$ and KAR1 $\left(3 \times 10^{-9} \mathrm{M}\right)$ are very helpful to remove seed dormancy and increase seed germination. To check this we measured the ABA and GA contents in the presence of $\mathrm{NO}(5 \mathrm{mM})$ and KAR1 $\left(3 \times 10^{-9} \mathrm{M}\right)$ for 1, 2, 3 and $4 \mathrm{~d}$ (Fig. 4a and b). We recoded the increasing pattern of $\mathrm{ABA}$ and GA contents in control samples during whole incubation period. Highest ABA (24 ng/25 seeds) and GA contents ( $5.5 \mathrm{ng} / 25$ seeds) were recorded after $4 \mathrm{~d}$ of application in non-treated samples (Fig. $4 \mathrm{a}$ and b). Lowest ABA contents ( $6.5 \mathrm{ng} / 25$ seeds) were recorded after $4 \mathrm{~d}$ of KAR1 application. Increase in GA contents was noticed during the whole incubation period. After $4 \mathrm{~d}$ of incubation higher GA contents were recorded in the presence of KAR1 (Fig. 4b).

\section{Ethylene production and ethylene inhibitor NBD}

An increase in ethylene production is known to play a major role in alleviating seed dormancy. To verify this, we measured ethylene production in the presence of ethylene inhibitor NBD and the increase/decrease in ethylene production in the presence of $\mathrm{NO}(5 \mathrm{mM})$ and KAR1 $\left(3 \times 10^{-9} \mathrm{M}\right)$. Ethylene production rates, either in

\section{The effect of KAR1 and NO on the contents of ABA and GA}
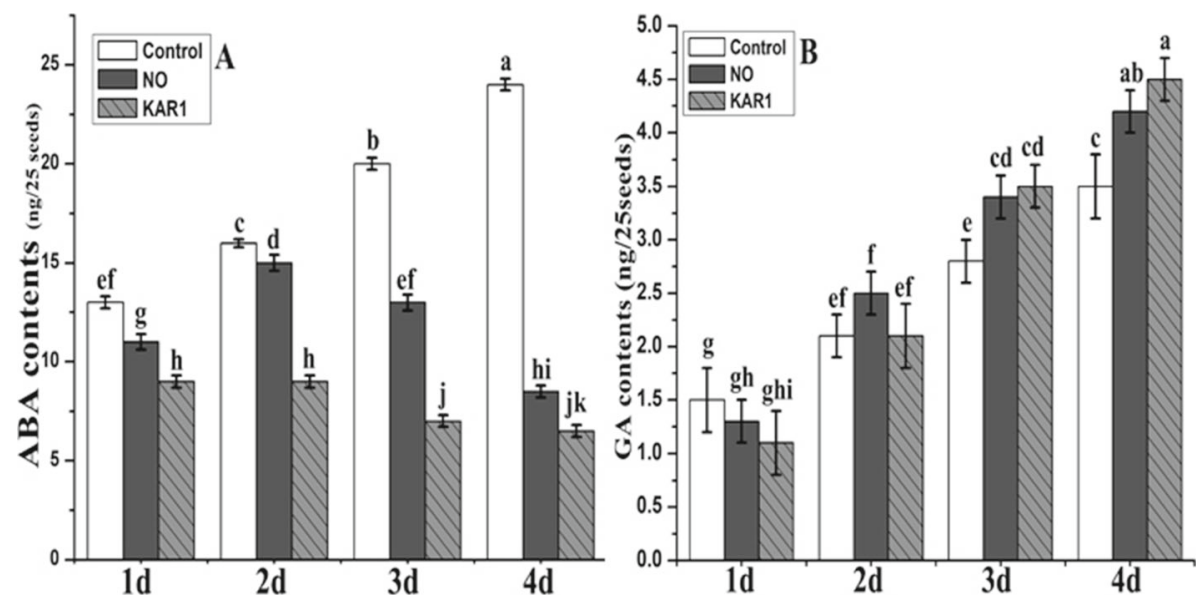

Fig. 4 Effects of $\mathrm{NO}(5 \mathrm{mM})$ and KAR1 $\left(3 \times 10^{-9} \mathrm{M}\right)$ on (a) ABA contents, b GA contents in secondary dormant Brassica oleracea seeds during imbibition at $21{ }^{\circ} \mathrm{C}(n=3)$. Values are mean \pm SE. Significant differences between treatments determined by two-way analysis of variance (ANOVA), followed by HSD Tukey's test. Means with different letters are significantly different at $p<0.05$. KAR1, karrikin1; NO, Nitric oxide; ABA, abscisic acid; GA, gibberellic acid; d, days 
water or NO and KAR1-treated, were determined at different time-points $(12,24,36$ and $48 \mathrm{~h}$ ) of imbibition (Fig. 5a). Seeds were incubated in NO and KAR1 or in water for $12,24,36$, and $48 \mathrm{~h}$. ACC $\left(1 \times 10^{-4} \mathrm{M}\right)$ was also applied, either alone or in combination with $\mathrm{NO}$ or KAR1. The level of ethylene was lower at $12 \mathrm{~h}$ of incubation in the presence of NO. The untreated seeds started producing ethylene after $24 \mathrm{~h}$ of incubation at a relatively low stable level. However, in the presence of ACC, no significant changes were observed in ethylene production. Both NO and KAR1 applied in combination with ACC increased ethylene production about twofold after $48 \mathrm{~h}$ of imbibition, indicating the ACO activation.

An ethylene binding inhibitor, NBD $\left(6 \times 10^{-5}\right.$ and $3 \times$ $10^{-5} \mathrm{M}$ ) was applied to also examine whether ethylene action is involved or not in the response of secondary dormant seeds to NO and KAR1. Brassica oleracea seeds germinated poorly in control samples at $21^{\circ} \mathrm{C}$ after $4 \mathrm{~d}$ (Fig. 5b), while seeds treated with $\mathrm{NO}(5 \mathrm{mM})$ and KAR1 $\left(3 \times 10^{-9} \mathrm{M}\right)$ showed $92 \%$ germination. Our experiment also demonstrated that ethylene signaling inhibitors like NBD can markedly inhibit the germination of Brassica seeds induced by NO and KAR1. Only 25$55 \%$ of NO seed germinations and $36-46 \%$ of KAR1 seed germinations were recorded, as shown in (Fig. 5b).

\section{ACC contents and activities of ACS and ACO}

ACC is the direct precursor of ethylene biosynthesis. In order to determine ACC contents, seeds were incubated in NO $(5 \mathrm{mM})$ and KAR1 $\left(3 \times 10^{-9} \mathrm{M}\right)$ solutions or in water for $12,24,36$, and $48 \mathrm{~h}$. ACC contents recorded at 12 and $48 \mathrm{~h}$ of incubation in water were 0.4 and
$0.45 \mu \mathrm{mol} \mathrm{g}^{-1} \mathrm{FW}$, respectively. Little increase $(0.5 \mu \mathrm{mol}$ $\left.\mathrm{g}^{-1} \mathrm{FW}\right)$ was recorded after that at 24 and $36 \mathrm{~h}$, while little decrease $\left(0.45 \mu \mathrm{mol} \mathrm{g}^{-1} \mathrm{FW}\right)$ was noted after $48 \mathrm{~h}$ (Fig. 6a). In the presence of NO at $12 \mathrm{~h}, \mathrm{ACC}$ contents were low $\left(0.3 \mu \mathrm{mol} \mathrm{g}^{-1} \mathrm{FW}\right)$, but started increasing over time and maximum ACC contents $\left(0.92 \mu \mathrm{mol} \mathrm{g}^{-1} \mathrm{FW}\right)$ were noted after $48 \mathrm{~h}$ (Fig. 6a). The same pattern was observed in the presence of KAR1: after $12 \mathrm{~h}$, ACC contents were $0.6 \mu \mathrm{mol} \mathrm{g}{ }^{-1} \mathrm{FW}$ (twice that of the NO treatment), and a continuous increase was observed in the presence of KAR1 until the end of incubation. After $48 \mathrm{~h}$, maximum ACC contents $\left(1.1 \mu \mathrm{mol} \mathrm{g}{ }^{-1} \mathrm{FW}\right)$ were noted (Fig. 6a).

ACS and ACO activities increase ethylene production and are (directly or indirectly) helpful in alleviating seed dormancy. To determine ACS and ACO activities, seeds were incubated in water or $\mathrm{NO}(5 \mathrm{mM})$ and KAR1 $(3 \times$ $10^{-9} \mathrm{M}$ ) solutions for $12,24,36$, and $48 \mathrm{~h}$. The ACS activity was relatively low with no significant changes observed in the control culture (Fig. 6b), while the ACS activity increased two to three-fold after 24 and $36 \mathrm{~h}$ of incubation in the presence of NO and KAR1. However, in NO pretreated samples, the ACS level decreased after $48 \mathrm{~h}$ of imbibition.

ACO activity was also low at the start of the incubation period, in both treated and non-treated samples (Fig. 6c). However, the ACO activity increased rapidly after $36 \mathrm{~h}$ of both NO and KAR1 treatments, a twofold increase in comparison to the control (Fig. 6c). The significant stimulatory effects of NO and KAR1 on ACO activity in vitro were also observed after $48 \mathrm{~h}$ of imbibition (Fig. 6c), and ACO activity reached its maximum.

\section{Ethylene production and Ethylene inhibitor NBD}

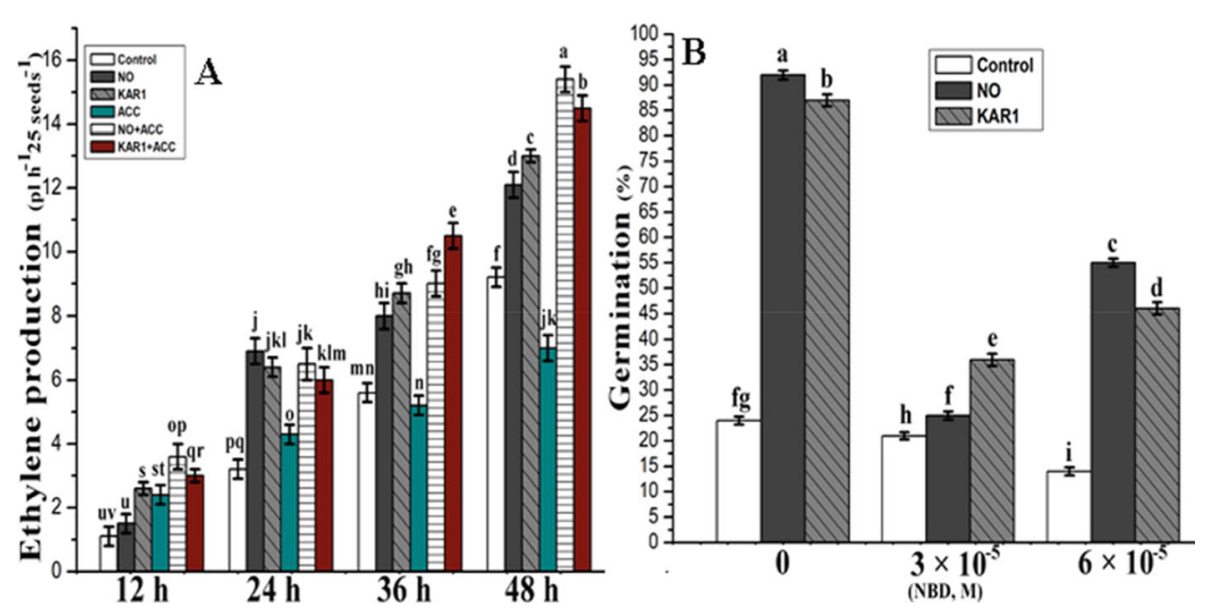

Fig. 5 Effects of $\mathrm{NO}(5 \mathrm{mM})$ and KAR1 $\left(3 \times 10^{-9} \mathrm{M}\right)$ on (a) Ethylene Production, $\mathbf{b} \mathrm{NBD}$ in secondary dormant Brassica oleracea seeds during imbibition at $21{ }^{\circ} \mathrm{C}(n=3)$. Values are mean \pm SE. Significant differences between treatments determined by two-way analysis of variance (ANOVA), followed by HSD Tukey's test. Means with different letters are significantly different at $p<0.05$. KAR1, karrikin1; NO, Nitric oxide; NBD , 2,5norbornadiene; h, hours 


\section{ACO contents, ACS and ACO activities}
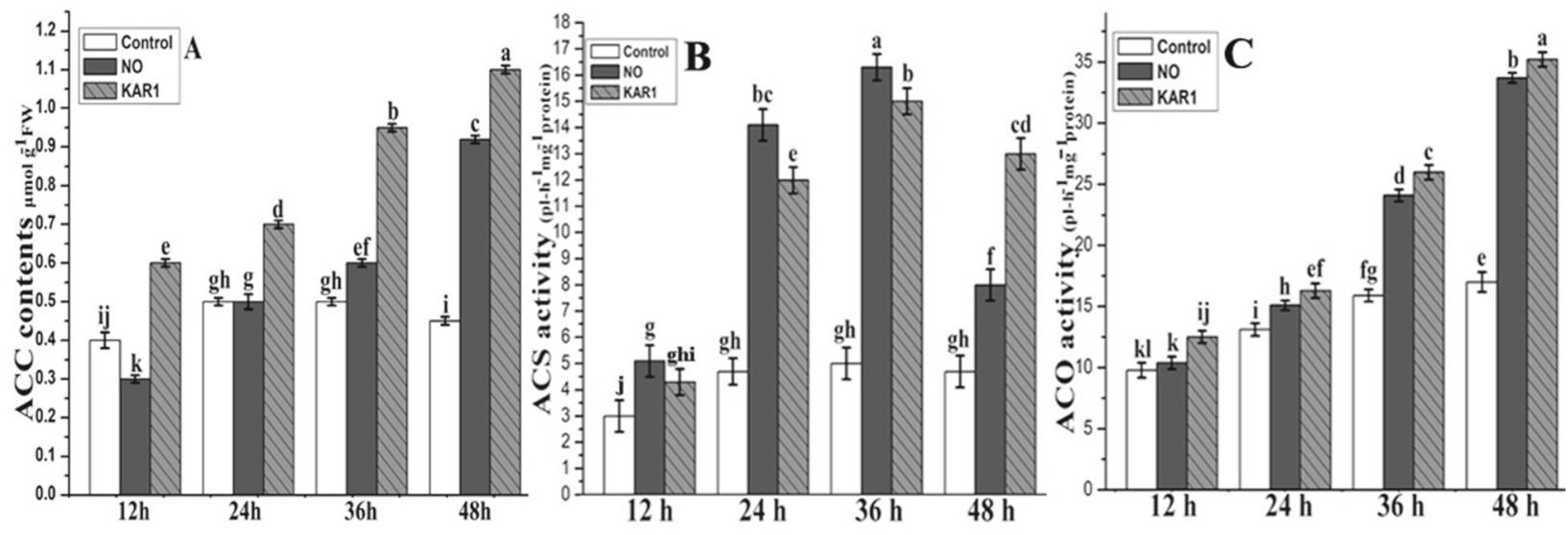

Fig. 6 Effects of NO (5 mM) and KAR1 (3 × 10-9 M) on (a) ACC contents, (b) ACS activity, (c) ACO activity in secondary dormant Brassica oleracea seeds during imbibition at $21^{\circ} \mathrm{C}(n=3)$. Values are mean \pm SE. Significant differences between treatments determined by two-way analysis of variance (ANOVA), followed by HSD Tukey's test. Means with different letters are significantly different at $p<0.05$. KAR1, karrikin1; NO, Nitric oxide; ACC synthase, ACS, ACC oxidase, ACO; h, hours

\section{Relative expression of Brassica oleracea ethylene-related} genes

To thoroughly check the effects of NO $(5 \mathrm{mM})$ and KAR1 $\left(3 \times 10^{-9} \mathrm{M}\right)$ on ethylene production, we observed the expression of ethylene-related genes. The relative expression of genes encoding biosynthetic enzymes (one ACO oxidase (BOACO1), seven ACS synthases (BOACS1, BOACS3, BOACS4, BOACS5, BOACS7, $B O A C S 9$, and $B O A C S 11)$ and two ethylene receptor (BOETR1 and BOETR2) genes) was analyzed during the imbibition of seeds in water at different incubation periods $(0,12,24,36$ and $48 \mathrm{~h})$ (Fig. 7a, b and c). When compared to dry $(0 \mathrm{~h})$ seeds, the level of BOACS1 transcripts remained unchanged during the whole period of incubation, while BOACS3, BOACS5, BOACS9 and $B O A C S 11$ were up-regulated. However BOACS4 and $B O A C S 7$ were down-regulated to a different extent during incubation in water (Fig. $7 \mathrm{a}, \mathrm{b}$ and $\mathrm{c}$ ). Both BOETR1 and BOETR2 were also up-regulated, as shown in Fig. 7a.

In the presence of $\mathrm{NO}(5 \mathrm{mM})$ and KAR1 $\left(3 \times 10^{-9}\right.$ $\mathrm{M})$, gene expression analyses were also carried out for all genes mentioned above with different incubation

\section{The relative expression of Brassica oleracea genes}
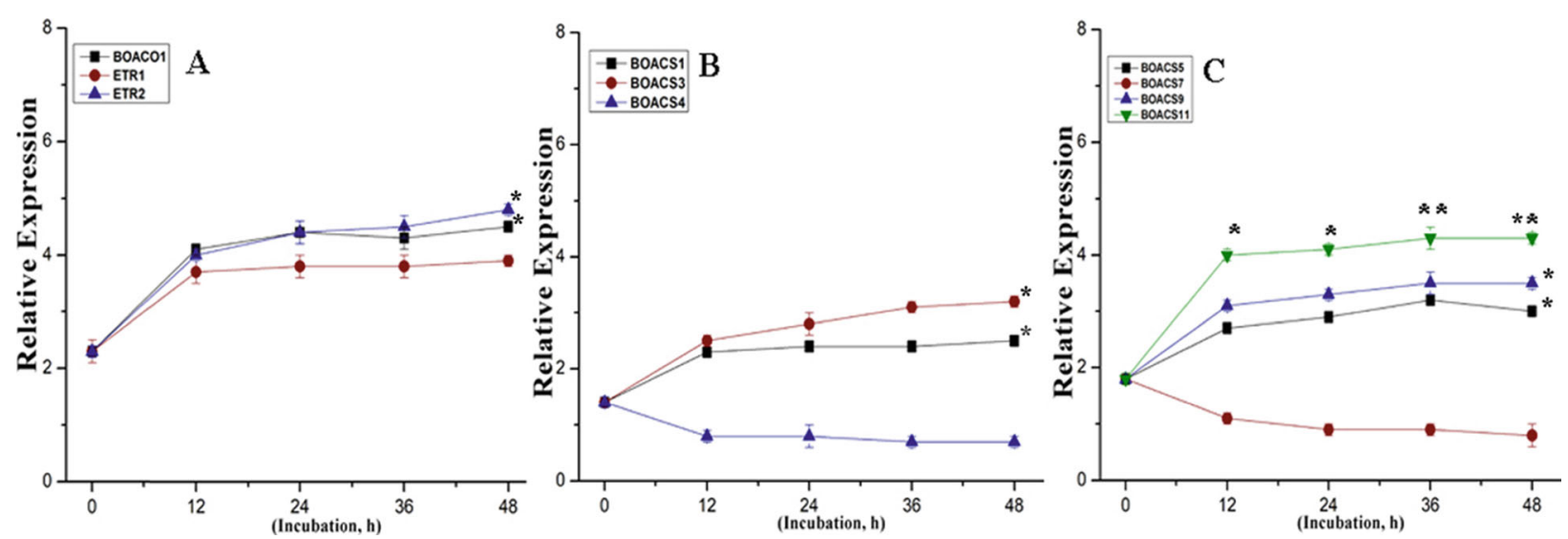

Fig. 7 Relative expression patterns of BOACO1 and ethylene receptor genes (a) and ethylene biosynthesis genes (BOACS1, BOACS3, BOACS4, BOACS5, BOACS7, BOACS9, and BOACS11) (b, c) in secondary dormant Brassica oleracea seeds incubated in water at $21^{\circ} \mathrm{C}$. Transcript levels for each gene were estimated by qRT-PCR. The fold changes indicate the expression patterns of analyzed genes relative to their transcript levels in dry seeds ( $0 \mathrm{~h}$ of incubation) with assumed value of 1. Statistical analyses: two-way ANOVA with post hoc Tukey's (HSD) test with confidence interval 0.05 , significance between groups indicated as ${ }^{*}$ for $P \leq 0.05$ and ${ }^{* *}$ for $P \leq 0.01$ 
periods (0, 12, 24, 36 and $48 \mathrm{~h}$ ) (Fig. 8). BOACT1 (actin gene) was used as the reference gene. Almost no change was observed in the expression of all genes at $0 \mathrm{~h}$ (Fig. 8 ). The level of BOACS1 was lower after 12, 36 and $48 \mathrm{~h}$, but after $24 \mathrm{~h}$, the level was higher in the presence of KAR1 $\left(3 \times 10^{-9} \mathrm{M}\right)$ than the control treatment (Fig. 8a and $b$ ). In the presence of KAR1, the expression of $B O A C S 2$ was higher after 12,24 and 48 , but was nearly the same after $36 \mathrm{~h}$ in comparison to the control treatment. While in the presence of $\mathrm{NO}(5 \mathrm{mM})$, the levels of both genes were higher and a significant difference was noted in comparison to the control. BOACS4 and $B O A C S 5$ showed lower expression under NO application in comparison to KAR1 and control (Fig. 8c and d). The expression levels of the remaining three genes (BOACS7, BOACS9 and BOACS 11) were higher and more significant in both treatments than in the control treatment (Fig. 8e, f and g). The ethylene receptor genes,
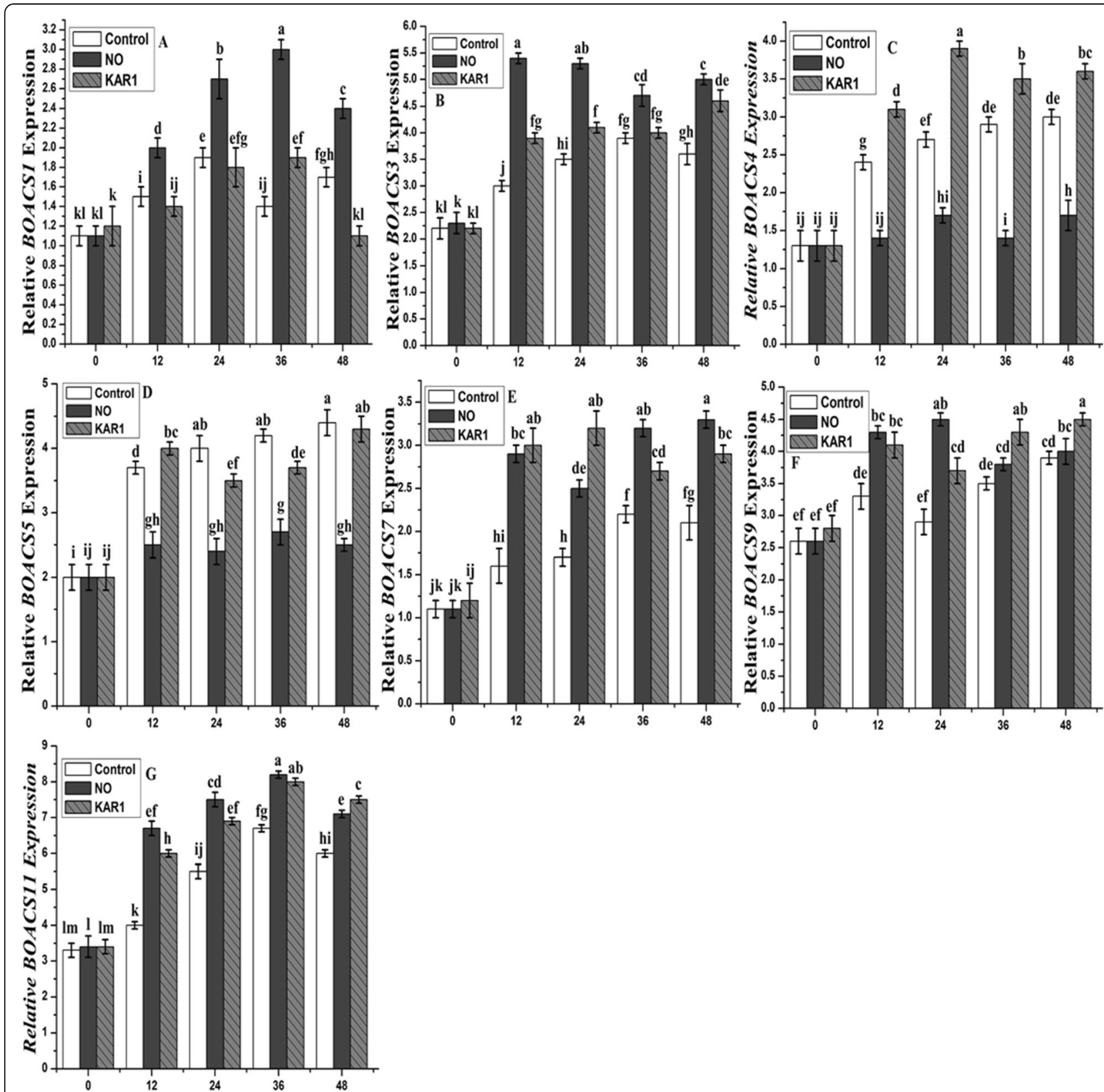

Fig. 8 Effects of $\mathrm{NO}(5 \mathrm{mM})$ and KAR1 $\left(3 \times 10^{-9} \mathrm{M}\right)$ on (a) BOACS1, b BOACS3, c BOACS4, d BOACS5, e BOACS7, f $B O A C S 9$, g BOACS11 genes in secondary dormant Brassica oleracea seeds during imbibition at $21{ }^{\circ} \mathrm{C}(n=3)$. Values are mean \pm SE. Significant differences between treatments determined by two-way analysis of variance (ANOVA), followed by HSD Tukey's test. Means with different letters are significantly different at $p<$ 0.05. KAR1, karrikin1; NO, Nitric oxide; h, hours 
BOETR1 and BOETR2, were up-regulated to a different extent during imbibition (Fig. $9 \mathrm{~b}$ and c). BOETR1 showed a stable twofold induction of its transcriptional activity when measured 12 to $48 \mathrm{~h}$ after imbibition (Fig. 9b), while about a threefold change in the transcript level was observed for BOETR2 (Fig. 9c). Contrasting results were obtained for genes encoding biosynthetic enzymes (Fig. 9a). The expression of the BOACO1 gene was higher after 36 and $48 \mathrm{~h}$ of incubation (Fig. 9a) in the presence of NO, while the presence of KAR1 showed a slightly lower expression level than the control.

\section{Discussion}

\section{Effect of NO and KAR1 on seed germination, hydrogen} peroxide and superoxide anion levels

Our experimental data showed that secondary dormant Brassica oleracea seeds (poorly germinated at $21^{\circ} \mathrm{C}$ ) are in a state of dormancy (Fig. 1). The NO $(5 \mathrm{mM})$ and KAR1 $\left(3 \times 10^{-9} \mathrm{M}\right)$ treatments effected on Brassica oleracea dormant seeds germination (Fig. 1a). NO and KAR1 treatments successfully removed the seed dormancy in secondary dormant Brassica oleracea seeds. Our findings (Fig. 1) that both NO and KAR1 can break seed dormancy and induce seed germination is in agreement with previous studies [13, 44]. Past studies have also proved that the NO present in the surrounding environment can enhance germination at the early stages of seed germination [45]. However, further investigations are still required to fully understand the regulatory role of NO and KAR1 in breaking dormancy.

Seed dormancy alleviation not only depends on plant hormones, but it is also regulated by $\operatorname{ROS}\left(\mathrm{H}_{2} \mathrm{O}_{2}\right.$ and $\left(\mathrm{O}_{2}{ }^{-{ }^{-}}\right)$activities. ROS are small molecules in plant tissues and seeds that play a dual role in toxicity and signaling [31]. In the seed germination process, ROS are released into the surrounding environment to facilitate radical production [46]. Previous studies have shown that ROS accumulation is essential for various plant species in breaking seed dormancy and regulating seed germination [31, 47]. KAR1 and NO-induced seed germination is also associated with $\mathrm{H}_{2} \mathrm{O}_{2}$ and $\mathrm{O}_{2}{ }^{\cdot-}$ accumulation (Fig. 2). In the early stages of seed germination, the production of $\mathrm{ROS}\left(\mathrm{H}_{2} \mathrm{O}_{2}\right.$ and $\left.\mathrm{O}_{2}{ }^{\circ}\right)$ indicates a positive biological reaction with successive germination and vigorous seedling growth. A previous study also confirmed that $\mathrm{H}_{2} \mathrm{O}_{2}$ production can break seed dormancy during the early phases of seed germination [32]. The data in our experiment show that $\mathrm{H}_{2} \mathrm{O}_{2}$ and $\mathrm{O}_{2}{ }^{-{ }^{-}}$accumulation/application were not harmful to Brassica seeds with a high viability (expressed as seed germination) in $\mathrm{NO}$ and KAR1 treated samples. This may be due to the cellular antioxidant system [48], which is also implied in Fig. 2. Similar interesting results were also noticed in apple seeds treated with $\mathrm{NO}$ and $\mathrm{HCN}$ [11].

\section{Effect of NO and KAR1 on antioxidant enzymes, ABA and GA level}

The stimulatory effect of KAR1 on seed dormancy and seed germination has been reported by many researchers $[11,44,49]$. SOD is the primary antioxidant [50], playing a crucial role in controlling plant oxidative stress. SOD and CAT are mainly localized in mitochondria and peroxisomes, and are not sensitive to $\mathrm{H}_{2} \mathrm{O}_{2}$. Our study indicates that Brassica oleracea seeds treated with $\mathrm{NO}$ and KAR1 did not significantly change CAT and SOD activity only a slight stimulation of CAT activity (Fig. 3) was recorded. Additionally, neither NO nor KAR1 significantly altered SOD and CAT activity (Fig. 3). NO and KAR1 enhanced CAT and SOD activities to their maximum level after 2 days of treatments. Subsequently, SOD levels decreased to $5 \%$ as the time of treatment increased (Fig. 3). CAT activity also decreased after 3

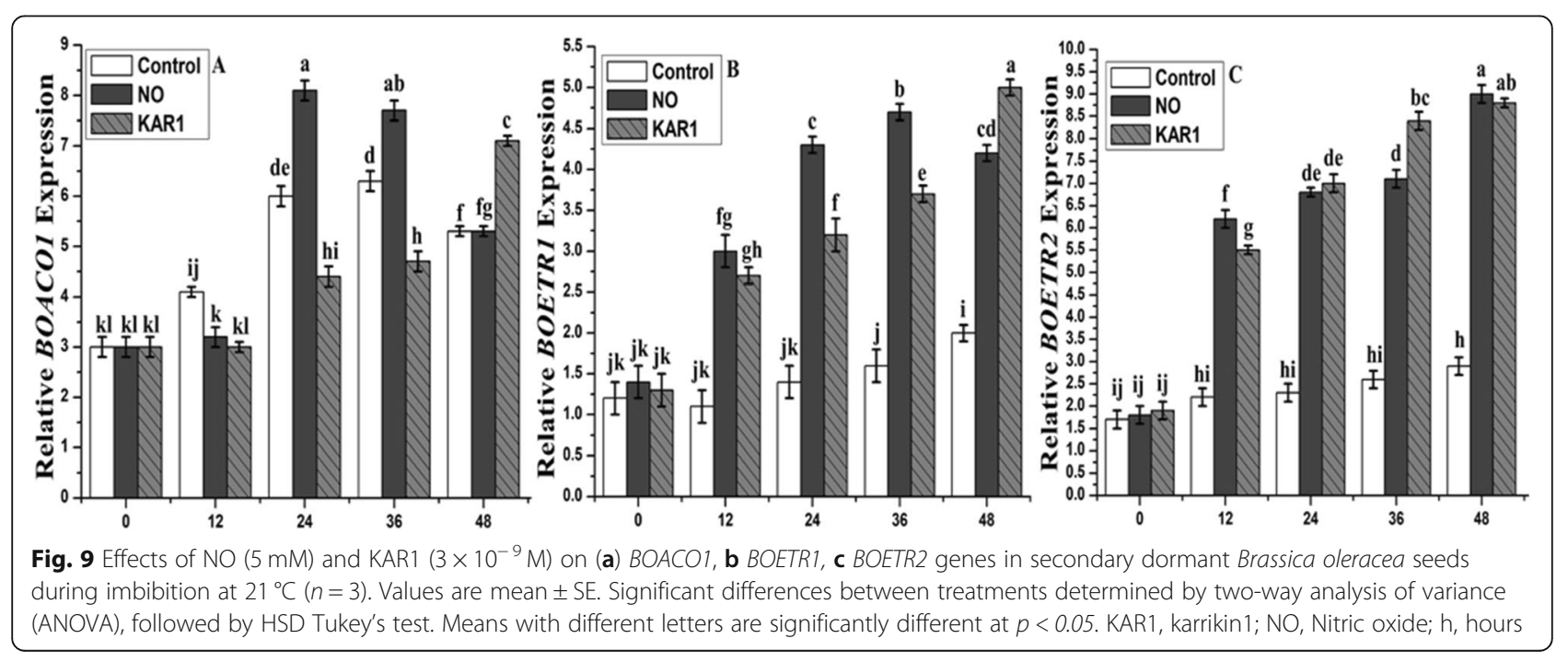


and 4 days of application (Fig. 3). Similar to our findings, previous studies have demonstrated that gibberellic acid down-regulates SOD and CAT activities in barley [51], and in A. fatua, CAT and SOD activity were downregulated by GA3 and KAR1 [52]. NO and KAR1 progressively enhance the GR level (Fig. 3c). Comparison of the GR activity and CAT and SOD activity in NO- and KAR1-treated Brassica samples suggest that GR activity is positively correlated with duration of application.

In the present study we observed the combined effect of KAR1 and NO on ABA and GA to release the seed dormancy (Fig. 4). Both NO and KAR1 were found to reduce ABA contents and increase in GA contents. In previous studies, GA is observed as negative while ABA is noted as positive regulator for seed dormancy development $[18,53]$. Dormancy release by KAR1 and NO in Brassica was accompanied by degradation of ABA level (Fig. 4). Previous [38] study also supported our results; seed dormancy release also depends upon an increase in GA contents and decrease in ABA contents. Previous studies exhibited that in dormant Arabidopsis thaliana seeds, KAR1 is required for GA biosynthesis [6].

\section{Effect of NO and KAR1 on ethylene and ethylene inhibitor NBD}

The role of ethylene in the alleviation of seed dormancy and the regulation of seed germination is still not fully understood [20]. Our study, combined with an analysis of the ethylene biosynthetic pathway and application of NBD, clearly show that in the presence of NBD, NO and KAR1 have no significant effect on seed germination (Fig. 5), mainly due to NBD inhibiting ethylene action (Fig. 5). The stimulating effects of NO and KAR1 are dependent on ethylene signaling, even when both are inhibited by 2,5-NBD ethylene inhibitor (Fig. 5). Our findings are in agreement with [54], who found that NBD inhibited the ethylene production in apple seeds, germination of barley and sunflower seeds $[55,56]$. In study, we found that ethylene strengthened the influence of KAR1 and NO pre-treatment during the regulation of Brassica oleracea seed germination. Our study proves that both molecules, KAR1 and NO, regulate seed germination in an ethylene-dependent manner (Fig. 5). Experiments with NBD suggest that ethylene is necessary for Brassica seed germination.

Effect of NO and KAR1 on ACS, ACO and ethylene related genes.

In this study, ACS activity was relatively low during the germination of Brassica oleracea seeds after $12 \mathrm{~h}$ under KAR1 and NO applications (Fig. 6a). KAR1 and $\mathrm{NO}$ induced the fast increase of ACS and ACO activities after 24 and $36 \mathrm{~h}$ of incubation; after $48 \mathrm{~h}$, ACS activity declined but ACO activity increased (Fig. 6a and b). However, our experiment suggests that even low activities of ACS and ACO can stimulate dormancy removal. Previous study [17] also found that seed dormancy may be the outcome of low ACC concentration in seeds due to insufficient ACS activity. The pretreatment of Brassica seeds with NO and KAR1 increased the activity of the ACO enzyme (Fig. 6b). In Pisum sativum seed germination, ethylene regulated the ACO activity [57]. Our results show that during the initial stages of Brassica seed germination, the conversion of ACC into ethylene may be independent of ACO. In Arabidopsis thaliana, Pisum sativum, Lepidium sativum, and beechnut seeds, the relationship between ACO activity and ACO transcripts, proposed regulation at a transcriptional level during alleviation of dormancy [25, $26,57]$.

It has been speculated that ethylene production level, and ACS and ACO gene coding enzymes could be involved in ethylene biosynthesis and seed germination, and our results seem to support this hypothesis (Fig. 6). Previous studies indicated that ethylene could regulate its own synthesis through ACO regulation [13, 44]. Similar mechanisms can also be observed in citrus leaves or in the epicotyls of pea seedlings [58].

In the formation of the ethylene precursor (ACC), ACS genes are dependent on pyridoxal phosphate (PLP). In our study, we selected seven ACS genes and one ACO gene, and found that their expression levels correlated with ethylene production (Fig. 7). Genes with high expression level related with high ethylene production. The ACO genes are responsible for conversion of ACC to ethylene. The expression of ACO and ACS genes was not the same under NO and KAR1 applications. The expressions of $B O A C S 1, B O A C S 3, B O A C S 5, B O A C S 9$ and $B O A C S 11$ were up-regulated, and BOACS4 and BOACS7 were down-regulated to a different extent during incubation in water (Fig. 7a, b and c). ACO and ACS genes upregulation modulated ethylene production under $\mathrm{NO}$ and KAR1 applications (Fig. 8).

Previous studies also found different types of ethylene receptors (ETR) in plants [59]. In this study, we used two different types of ethylene receptor genes (BOETR1 and BOETR2) and found that these two genes were different in their expressions and function (Figs. 7 and 9). BOERT2's expression level was higher than that of BOETR1 under NO and KAR1 treatments. In transgenic tomato plants, the ethylene response is determined by the rate of receptor expressions [60]. Previously [48] found that ethylene receptors that were not bound to ethylene were considered negative regulators because they inhibited the ethylene signal transduction pathway. Ethylene production did not increase significantly during incubation in water (Fig. 5a), suggesting that any ethylene-dependent process might be inhibited during seed dormancy alleviation. In Brassica dormant seeds, 
both ethylene receptor genes BOETR1 and BOETR2 were up-regulated during water incubation (Fig. $7 \mathrm{~b}, \mathrm{c}$ ). The low sensitivities of BOETR1 and BOETR2 to ethylene might be caused by their up-regulation and during incubation in NO and KAR1, both of these receptors exhibited up-regulation. These findings are similar to previous reported findings, proposing the stimulatory influence of NO and KAR1 and the ethylene signaling pathway on seed dormancy release [10, 11, 61, 62]. Some similarities have been detected between NO and KAR1, such as both molecules acting via ethylene in breaking dormancy. In conclusion, we have successfully alleviated nearly $98 \%$ of the seed dormancy of Brassica olereace after 7 days of NO and KAR1 treatments that modified the ethylene pathway and antioxidant enzyme activity.

\section{Conclusion}

Imbalances between antioxidant enzymes, hydrogen peroxide, superoxide anion, and low levels of ethylene lead to seed dormancy in plants. NO $(5 \mathrm{mM})$ and KAR1 $(3 \times$ $10^{-9} \mathrm{M}$ ) treatments alleviates the seed dormancy of Brassica oleracea seeds and enhances the hydrogen peroxide, superoxide anion, GA contents, antioxidant enzyme, and ethylene levels required to induce seed germination. Ethylene modulation seems to be an important factor in seed germination induction. However, further studies are required to fully reveal the pathway components, determine the hierarchy of these two compounds, and identification of responsible target genes that would help elucidate the precise roles of NO, KAR1, and ethylene in the secondary dormant Brassica oleracea germination process.

\section{Material and methods}

\section{Plant material, growth conditions and determination of} water contents

Secondary dormant Brassica oleracea L. seeds were collected from the rapeseed cultivation and breeding lab of Anhui Agricultural University, China. Seeds (25 seeds each in three replicates per treatment) were imbibed in water in the presence of infrared light $\left(100 \mu \mathrm{mol} \cdot \mathrm{m}^{2} \cdot \mathrm{s}^{-1}\right.$ radiation) at $5{ }^{\circ} \mathrm{C}$ under osmotic potential of $-1600 \mathrm{kPa}$ for 4 days to induce secondary dormancy. After 4 days seeds were stored at $-20^{\circ} \mathrm{C}$. Seeds were sterilized by washing with $3 \%$ sodium hypochlorite (Aladin, Shanghai, China), then incubated in distilled water for $8 \mathrm{~h}$, followed by imbibition on pre-wetted muslin cloth for 1 day. The imbibed seeds were cultured in growth chambers under $16 \mathrm{~h}$ light and $8 \mathrm{~h}$ dark cycle conditions at $21^{\circ} \mathrm{C}$ and $70 \%$ relative humidity.

To check seed germination [1]; filter paper placed in the petri dishes and moistened with (a) $1.5 \mathrm{ml}$ of distilled water, or (b) KAR1 $\left(3 \times 10^{-9} \mathrm{M}\right)$ or $(\mathrm{c}) \mathrm{NO}(5 \mathrm{mM})$ and [2] seeds were placed on wetted filter paper and covered with a transparent lid for 5 days. After every $24 \mathrm{~h}$, germination percentage was recorded up to 5 days. Seeds with visible white radicle ( $1 \mathrm{~mm}$, after the seed coat was broken) were recorded as germinated. To protect germination from light effect or damage, seeds were grown in growth chamber under a green, safe light at $0.5 \mu \mathrm{mol} \mathrm{m} \mathrm{m}^{-2} \mathrm{~s}^{-1}$. In order to determine the water contents of treated and non-treated seeds (25 seeds each in three replicates per treatment), seeds were placed on a roller (at $10^{\circ} \mathrm{C}$ for $24 \mathrm{~h}$ ). Water contents were examined by oven-drying the seeds for $5,10,20,30,40$ and $50 \mathrm{~h}$, at $105^{\circ} \mathrm{C}$.

\section{KAR1 synthesis and treatment of Brassica seeds with NO or KAR1 or ACC}

KAR1 was prepared by the direct use of methyl pyruvate, dihydro-2H-pyran-3-(4H)-one and Ti-cross aldol [63]. To get the crystal compound, silica gel column chromatography was used to purify the obtained product. HRMS and $1 \mathrm{H}$ NMR analysis were performed to confirm the structure. NMR was analyzed (using CD13 as a solvent) on a Bruker AC 200 spectrometer with 200.13MHZ frequency. HRMS was analyzed on a Finnigan MAT 95 spectrometer.

The influence of nitric oxide in light on seed germination was examined following [14] method. HCL (0.1 M) and sodium nitrite $(20 \mathrm{mM})$ were used to prepare acidified nitrite, as recommended previously [11]. The seeds (25 seeds each in three replicates per treatment) were washed using distilled water, following this, seeds were placed on filter paper (one layer) in petri dishes and moistened either with; (a) $1.5 \mathrm{ml}$ of distilled water, or (b) KAR1 (3x $10^{-9} \mathrm{M}$ ) with or without1-aminocyclopropane-1-carboxylic acid (ACC $\left.1 \times 10^{-4} \mathrm{M}\right)$, or $(\mathbf{c}) \mathrm{NO}(5 \mathrm{mM})$ with or without1-aminocyclopropane-1-carboxylic acid (ACC $1 \times$ $10^{-4} \mathrm{M}$ ), or (d) 1-aminocyclopropane-1-carboxylic acid $\left(\right.$ ACC $\left.1 \times 10^{-4} \mathrm{M}\right)$.

\section{Hydrogen peroxide $\left(\mathrm{H}_{2} \mathrm{O}_{2}\right)$ and superoxide anion $\left(\mathrm{O}_{2}{ }^{-}\right)$ concentration measurement}

Previous methodology [64] was used to measure the concentration level of $\mathrm{H}_{2} \mathrm{O}_{2}$ in seeds. Seeds (25 seeds each in three replicates per treatment) were homogenized in ice with $3 \mathrm{ml}$ cold TCA $0.1 \%(\mathrm{w} / \mathrm{v})$. The obtained mixture was centrifuged for $15 \mathrm{~min}$ at $4{ }^{\circ} \mathrm{C}$ at 13,000 RPM. Then $(0.5 \mathrm{ml})$ supernatant and $1 \mathrm{ml}$ freshly prepared $\mathrm{KI}(1 \mathrm{M})$ were added to $0.5 \mathrm{ml}$ potassium phosphate buffer $(10 \mathrm{mM}$ and $\mathrm{pH} 7.0)$. $\mathrm{H}_{2} \mathrm{O}_{2}$ absorbance was measured using a spectrophotometer (Shanghai Yoke Instrument, Shanghai, China) at $390 \mathrm{~nm}$.

Previous methodology [65] was followed to measure the concentration levels of superoxide anion in secondary dormant Brassica oleracea seeds. Seeds (25 seeds each in three replicates per treatment) were homogenized on ice with $3 \mathrm{ml}$ cold TCA $0.1 \%(\mathrm{w} / \mathrm{v})$. The obtained mixture was centrifuged at $13,000 \mathrm{RPM}$ at $4{ }^{\circ} \mathrm{C}$ for $15 \mathrm{~min}$. 
Subsequently, $1.5 \mathrm{ml}$ supernatant and $1.5 \mathrm{ml}$ hydroxylamine hydrochloride $(1 \mathrm{mM})$ were mixed in $50 \mathrm{mM}$ potassium buffer ( $\mathrm{pH} 7.8$ ) in the absence of light and incubated for $30 \mathrm{~min}$ at $21^{\circ} \mathrm{C} .0 .5 \mathrm{ml}$ of the obtained mixture was then added to a mixture of $0.5 \mathrm{ml} \mathrm{2-naphthylamine} \mathrm{(7}$ $\mathrm{mM}$ ) and $0.5 \mathrm{ml}$ sulphanilamide $(17 \mathrm{mM}$ ) (in potassium buffer) and incubated for $30 \mathrm{~min}$ in the dark at $21^{\circ} \mathrm{C}$. The resultant mixture was again centrifuged for $10 \mathrm{~min}$ at 13 , 000 RPM. The absorbance of the superoxide anion was determined at A540 $\mathrm{nm}$ using a spectrophotometer (Shanghai Yoke Instrument, Shanghai, China). Sodium nitrite $\left(\mathrm{NaNO}_{2}\right)$ was used to prepare the calibration curve.

\section{Analysis of antioxidant enzyme (SOD, CAT, and GR) measurement}

EDTA (1 mM), 2\% PVP, PMSF (0.01 mM), and DTT (5 $\mathrm{mM}$ ) were used to ground the secondary dormant seeds (25 seeds each in three replicates per treatment) on ice.

Then resultant samples were added in $5 \mathrm{ml}$ potassium phosphate buffer $(0.1 \mathrm{M}$ and $\mathrm{pH} 7.0)$ and centrifuged for $15 \mathrm{~min}$ at $10,000 \mathrm{RPM}$ at $4{ }^{\circ} \mathrm{C}$. Then obtained mixture desalted in the presence of phosphate buffer using a Sephadex G-250 column (BioRad).

$\mathrm{HCl}(40 \mathrm{mM})$, glycine buffer ( $0.05 \mathrm{M}$ and $\mathrm{pH} 9.7)$ and $50 \mu \mathrm{l}$ epinephrine solution $(120 \mathrm{mM})$ were mixed together to a prepare reaction mixture, as previously described [66, 67] method. Samples $(50 \mu \mathrm{l})$ were homogenized in reaction mixture and acidified epinephrine was added to start reaction. A spectrophotometer (Shanghai Yoke Instrument, Shanghai, China) monitored the oxidation of epinephrine to adrenochrome at $480 \mathrm{~nm}$.

Aebi's [68] methodology was followed to measure the catalase (CAT) activity in secondary dormant seeds (25 seeds each in of three replicates per treatment). Samples $(50 \mu \mathrm{l})$ were homogenized in potassium phosphate buffer $(0.07 \mathrm{M})$ and $6 \% \mathrm{H}_{2} \mathrm{O}_{2}$ was added to start reaction. CAT activity was examined using a spectrophotometer (Shanghai Yoke Instrument, Shanghai, China) at $240 \mathrm{~nm}$.

Glutathione reductase (GR) activity was measured using [69] method. Twenty-five seeds each in three replicates per treatment were used to measure GR activity. GSSG $(5 \mathrm{mM})$ and potassium phosphate buffer $(0.05 \mathrm{M})$ were mixed together and samples were added in obtained mixture at $21^{\circ} \mathrm{C}$ for $10 \mathrm{~min}$. $\beta$-NADPH $(2 \mathrm{mM})$ was used to start reaction. GR activity was examined using a spectrophotometer (Shanghai Youke Instrument, Shanghai, China) at $340 \mathrm{~nm}$. Bradford's [70] methodology was used to measure the protein content. Bovine serum albumin (BSA) was used as a standard.

\section{Determination of $A B A$ and $G A$ contents}

ABA contents were measured according to [71] method. In presence of liquid nitrogen seeds ( 25 seeds in each of the three replicates per treatment) were ground into powder. Then samples were homogenized in methanol. D6-ABA was applied as an internal standard. To purify the samples, formic acid (7\%) was added in methanol in the presence of Oasis Max solid phase. In next step samples were injected into chromatography-tandem mass spectrometry system, equipped with a triple quadruple tandem mass spectrometer and ultra-performance liquid chromatograph.

Determination of GA contents was performed as described by [71] method. In the presence of liquid nitrogen, seeds ( 25 seeds in each of the three replicates per treatment) were ground into powder. Methanol $(85 \% \mathrm{v} / \mathrm{v})$ was used for extraction. The resultant mixture was purified by ethyl ether extraction, solid-phase extraction and reversed-phase. For quantitative analysis, samples were injected into capillary electrophoresis-mass spectrometry (CE-MS).

\section{Measurement of ethylene production and treatment with NBD}

Secondary dormant seeds ( 25 in each of the three replicates per treatment) were treated with (a) $\mathrm{NO}(5 \mathrm{mM})$, (b) KAR1 $\left(3 \times 10^{-9} \mathrm{M}\right)$, and (c) ACC $\left(1 \times 10^{-4} \mathrm{M}\right)$ or without ACC for 12, 24, 36, and $48 \mathrm{~h}$, as described previously [44]. In the presence of moistened filter paper, glass containers $(10 \mathrm{ml})$ were used to incubate the treated seeds in the dark at $21^{\circ} \mathrm{C}$ for $3 \mathrm{~h}$. A syringe was used to take the sample from glass container. Following that, sample $(1 \mathrm{ml})$ was injected into a Hewlett-Packard 5980 GC equipped with FID, a Pro pack Q 80/100 mesh and stainless steel column. Then samples were placed in an oven at $60^{\circ} \mathrm{C}$ for isothermal separation. The measuring unit for ethylene is $\mathrm{pl} \mathrm{h}^{-1} 25 \mathrm{seed}^{-1}$.

NBD, an inhibitor of ethylene, was applied to check the effect of ethylene on secondary seed germination. In tightly closed glass containers $(500 \mathrm{ml})$, secondary dormant seeds ( 25 in each of the three replicates per treatment) were placed on filter paper and moistened with; (a) KAR1 $\left(3 \times 10^{-9} \mathrm{M}\right)$, or $(\mathbf{b}) \mathrm{NO}(5 \mathrm{mM})$ in the presence of 2,5-norbornadiene (NBD), according to [44] method. NBD $\left(3 \times 10^{-5}\right.$ and $\left.6 \times 10^{-5} \mathrm{M}\right)$ in liquid form was applied under the lid of the container. After $5 \mathrm{~h}$ of treatment, seeds were rinsed three times with deionized water and positioned for germination assay.

\section{Determination of ACC contents, ACC synthase and ACC oxidase activities}

ACC contents were determined using [72] method. Ethanol $(2 \mathrm{ml}$ and $80 \% \mathrm{v} / \mathrm{v})$ was used to homogenized treated (with NO and KAR1) and non-treated seeds (25 seeds in each of the three replicates per treatment). To remove the ethanol, samples were centrifuged for $15 \mathrm{~min}$ at 13,000 RPM at $4{ }^{\circ} \mathrm{C}$. Following this, the ACC contents were 
measured at room temperature using a Hewlett-Packard $5980 \mathrm{GC}$. ACC content was calculated in $\mu \mathrm{mol} \mathrm{g}-1 \mathrm{FW}$.

ACC synthase (ACS) activity was examined using the [72, 73] method. Dithiothreitol (DTT) $5 \mathrm{mM}$, polyvinylpolypyrrolidone (PVPP) 2\% (w/v), phenylmethanesulfonyl fluoride (PMSF) $0.01 \mathrm{mM}$, HEPES- KOH buffer $(0.1$ $\mathrm{M} \mathrm{pH} \mathrm{8.5)} \mathrm{and} 10 \mu \mathrm{M}$ pyridoxal phosphate (PLP) were mixed together to prepare a homogenize buffer. Seeds were homogenized in homogenize buffer on ice.

Samples were vortexed for $10 \mathrm{~s}$ and then centrifuged at $4{ }^{\circ} \mathrm{C}$ for $15 \mathrm{~min}$ at $13,000 \mathrm{RPM}$.

To prepare the reaction mixture, PLP $(10 \mu \mathrm{M})$, HEPES- KOH (0.1 M and pH 8) and S-adenosyl methionine $(200 \mu \mathrm{M})$ were mixed together. Then samples were incubated (at $37^{\circ} \mathrm{C}$ ) in a glass container in the presence of reaction mixture $(0.6 \mathrm{ml})$ for $60 \mathrm{~min}$. $\mathrm{HgCl}_{2} 0.2 \mathrm{ml}$ $(10 \mathrm{mM})$ was used to stop reaction.

ACC oxidase in seeds was measured according to the [74] protocol. First, extraction buffer (E.B) was prepared by mixing glycerol $10 \%(\mathrm{v} / \mathrm{v}), 5 \%(\mathrm{v} / \mathrm{v})$ Triton X-100, Tris- $\mathrm{HCl} 0.1 \mathrm{M}, 7 \mathrm{mM}$ DTT, $25 \mathrm{mM}$ Na-ascorbate and $0.15 \mathrm{mM}$ PMSF and then samples were homogenized in $4 \mathrm{ml}$ E.B. ACC $2 \mathrm{mM}, \mathrm{NaHCO}_{3} 35 \mathrm{mM}$, DTT $1 \mathrm{mM}$, FeSO4 $25 \mu \mathrm{M}$, Na-ascorbate $30 \mathrm{mM}, \mathrm{NaHCO}_{3} 30 \mathrm{mM}$ and Tris- $\mathrm{HCl} 0.1 \mathrm{M}$ were used in the preparation incubation buffer. Samples were centrifuged at $4{ }^{\circ} \mathrm{C}$ for $15 \mathrm{~min}$ at 13,000 RPM, and the resultant mixture was added to incubation buffer. The obtained mixture (for 1 h) was placed on a shaking machine at $37^{\circ} \mathrm{C}$. ACO activity was calculated in $\mathrm{pl} \mathrm{h}^{-1} \mathrm{mg}^{-1}$ protein.

\section{RNA extraction and RT-qPCR of ethylene related genes}

To extract the RNA of secondary dormant Brassica oleracea seeds, seeds were pre-treated with NO $(5 \mathrm{mM})$ and KAR1 $\left(3 \times 10^{-9} \mathrm{M}\right)$ for $0,12,24,36$, and $48 \mathrm{~h}$ to observe the expression levels of ethylene related genes [49]. In this study, we selected 10 ethylene-related genes (Table 1). Twenty-five seeds (in each of the three replicates) were treated with (a) NO $(5 \mathrm{mM})$, or (b) KAR1 $\left(3 \times 10^{-9} \mathrm{M}\right)$, or (c) water. To prepare the first-strand cDNA, DNase I was added to $1 \mu \mathrm{g}$ aliquots of total RNA using an Omega BioTek kit (Biotechnology, Shanghai, China). Nuclease-free water was used for dilution (10\%) of obtained samples. Following this, SYBR Select master mix (Biotechnology, Shanghai, China) was used to perform RT-qPCR. Reactions were started at $95^{\circ} \mathrm{C}(10 \mathrm{~min})$ followed by 50 cycles amplification at $95^{\circ} \mathrm{C}(10 \mathrm{~s}), 60^{\circ} \mathrm{C}(20 \mathrm{~s})$, and $72^{\circ} \mathrm{C}(20 \mathrm{~s})$, and melting at $95^{\circ} \mathrm{C}$ (for $2: 30 \mathrm{~min}, 60^{\circ} \mathrm{C}, 30 \mathrm{~s}$ ), then continuously increased to $95^{\circ} \mathrm{C}$. Genes and qPCR primer sequences are given in Additional file 1: Table S1.

Table 1 List of primer sequences used in the experiments

\begin{tabular}{|c|c|c|c|}
\hline Gene Name & NCBI Reference Number & Direction & Primer Sequences $\left(5^{\prime} \ldots . . .3^{\prime}\right)$ \\
\hline \multirow[t]{2}{*}{ BO-ACS1 } & $X 82273$ & Forward & GCAGAGAAGCAAGACCAGAA \\
\hline & & Reverse & TTCTCGCCGTGTCCGTC \\
\hline \multirow[t]{2}{*}{ BO-ACS3 } & AF338652 & Forward & GGATAGTGATGAGTGGCGG \\
\hline & & Reverse & TCGGCGAGGCAGAACATA \\
\hline \multirow[t]{2}{*}{ BO-ACS4 } & AB086353 & Forward & GGATAGTGATGAGTGGCGG \\
\hline & & Reverse & CCCCGCCACTCATCACTA \\
\hline \multirow[t]{2}{*}{ BO-ACS5 } & AF074930 & Forward & TGAAAACCAGCTATGTTTCGATCTT \\
\hline & & Reverse & AAGATCGAAACATAGCTGGTITCA \\
\hline \multirow[t]{2}{*}{ BO-ACS7 } & AF338651 & Forward & CAAATGGGGCAAGCGGAGAATCAGG \\
\hline & & Reverse & СCTGATTCTCCGCTTGCCCCATTTG \\
\hline \multirow[t]{2}{*}{ BO-ACS9 } & AF074929 & Forward & TGCTITCTITTACCCACTC \\
\hline & & Reverse & GCTCCCGTTCTCCATTTC \\
\hline \multirow[t]{2}{*}{ BO-ACS11 } & AF074928 & Forward & AACAAACTACTATGTAAAAAATCCTG \\
\hline & & Reverse & AACTGATTCTTCGTITITITC \\
\hline \multirow[t]{2}{*}{ BO-ACO1 } & X81628 & Forward & GAGAAGTTGAGGATGTTGATTG \\
\hline & & Reverse & CCAATCAACATCCTCAACTTC \\
\hline \multirow[t]{2}{*}{ BO-ETR1 } & AF047476 & Forward & GCTCAAACACAGTCTITAGCGAC \\
\hline & & Reverse & ATCACACTAAACCTCGCACCAG \\
\hline \multirow[t]{2}{*}{ BO-ETR2 } & AB078598 & Forward & GGTGATAACCAACGGCAGG \\
\hline & & Reverse & CGTGGCTCCTTAGGCTGAA \\
\hline \multirow[t]{2}{*}{ BO-ACT1 } & AF044573 & Forward & GCTCCCAGGGCTGTITTC \\
\hline & & Reverse & CATCAGCCTCAGCCATTITT \\
\hline
\end{tabular}




\section{Statistical analysis}

Data presented in all graphs were mean \pm standard errors (SEs) using two-way analysis of variance (ANOVA). Multiple comparisons were made using Tukey's test. $P \leq$ 0.05 was used to measure the significant differences between the indicated treatment groups and control.

\section{Supplementary information}

Supplementary information accompanies this paper at https://doi.org/10. 1186/s12870-019-2118-y.

Additional file 1: Table S1. List of primer sequences used in the experiments.

\section{Abbreviations}

ACC: Synthase2,5-norbornadiene (NBD); ACO: Aminocyclopropane-1carboxylic acid ACC oxidase; CAT: Catalase; ETR: Ethylene receptors; GR: Glutathione reductase; $\mathrm{H}_{2} \mathrm{O}_{2}$ : Hydrogen peroxide; KAR1: Karrikin 1; NO: Nitric oxide; $\mathrm{O}_{2}{ }^{--}$: Superoxide anion; SOD: Superoxide dismutase

\section{Acknowledgements}

We thank to Prof. Dr. Ying Feng for guideline during whole work.

\section{Authors' contributions}

AS designed and performed the experiment, MWR and ZXY analyzed the data, $\mathrm{ZZH}$ and ZKJ provided the guidance during all experiments. All authors have read and approved the manuscript.

\section{Funding}

The research was financially supported by the 13th Five-Year Plan for Rapeseed-Cotton Industry System of Anhui Province in China (AHCYJSTX-04) and the National Key Research \& Development Program (2018YFD0100600).

\section{Availability of data and materials}

Sequence data from RNA-seq described in this article had been released at NCBI (https://www.ncbi.nlm.nih.gov/). The detailed information of genes and primers is listed in Additional file 1: Table S1.

\section{Ethics approval and consent to participate}

Not applicable

\section{Consent for publication}

Not applicable.

\section{Competing interests}

The authors declare that they have no competing interests.

Received: 1 August 2019 Accepted: 5 November 2019

Published online: 23 December 2019

\section{References}

1. Bewley JD. Seed germination and dormancy. Plant Cell. 1997:9(7):1055.

2. Huang S, Gruber S, Stockmann F, Claupein W. Dynamics of dormancy during seed development of oilseed rape (Brassica napus L.). Seed Sci Res. 2016;26(3):245-53.

3. KeÇpczyński J, KeÇpczyńska E. Ethylene in seed dormancy and germination. Physiol Plantarum. 1997;101(4):720-6.

4. Rodríguez-Gacio MD, Matilla-Vázquez MA, Matilla AJ. Seed dormancy and ABA signaling: the breakthrough goes on. Plant Signal Behav. 2009;4(11): 1035-48.

5. Dixon KW, Merritt DJ, Flematti GR, Ghisalberti EL. Karrikinolide-a phytoreactive compound derived from smoke with applications in horticulture, ecological restoration and agriculture. Acta Hortic. 2009;813: 155-70

6. Flematti GR, Ghisalberti EL, Dixon KW, Trengove RD. A compound from smoke that promotes seed germination. Sci. 2004;305(5686):977.

7. Nelson DC, Riseborough JA, Flematti GR, Stevens J, Ghisalberti EL, Dixon KW, Smith SM. Karrikins discovered in smoke trigger Arabidopsis seed germination by a mechanism requiring gibberellic acid synthesis and light. Plant Physiol. 2009:149(2):863-73.

8. Krasuska U, Ciacka K, Andryka-Dudek P, Bogatek R, Gniazdowska A. "Nitrosative Door" in Seed Dormancy Alleviation and Germination. In: Reactive Oxygen and Nitrogen Species Signaling and Communication in plants. Cham: Springer; 2015. p. 215-37.

9. Arc E, Galland M, Godin B, Cueff G, Rajjou L. Nitric oxide implication in the control of seed dormancy and germination. Frontiers Plant Sci. 2013;4:346.

10. Bethke PC, Gubler F, Jacobsen JV, Jones RL. Dormancy of Arabidopsis seeds and barley grains can be broken by nitric oxide. Planta. 2004;219(5):847-55.

11. Gniazdowska A, Krasuska U, Bogatek R. Dormancy removal in apple embryos by nitric oxide or cyanide involves modifications in ethylene biosynthetic pathway. Planta. 2010;232(6):1397-407.

12. Liu X, Deng Z, Cheng H, He X, Song S. Nitrite, sodium nitroprusside, potassium ferricyanide and hydrogen peroxide release dormancy of Amaranthus retroflexus seeds in a nitric oxide-dependent manner. Plant Growth Reg. 2011;64(2):155-61.

13. Kępczyński J, Sznigir P. Participation of GA 3, ethylene, NO and HCN in germination of Amaranthus retroflexus L. seeds with various dormancy levels. Acta Physiol Plantarum. 2014;36(6):1463-72.

14. Gniazdowska A, Dobrzyńska U, Babańczyk T, Bogatek R. Breaking the apple embryo dormancy by nitric oxide involves the stimulation of ethylene production. Planta. 2007;225(4):1051-7.

15. Hall BP, Shakeel SN, Schaller GE. Ethylene receptors: ethylene perception and signal transduction. J Plant Growth Reg. 2007;26(2):118-30.

16. Pierik R, Sasidharan R, Voesenek LA. Growth control by ethylene: adjusting phenotypes to the environment. JPlant Growth Reg. 2007;26(2):188-200.

17. Corbineau F, Xia Q, Bailly C, El-Maarouf-Bouteau H. Ethylene, a key factor in the regulation of seed dormancy. Frontiers Plant Sci. 2014;5:539.

18. Kucera B, Cohn MA, Leubner-Metzger G. Plant hormone interactions during seed dormancy release and germination. Seed Sci Res. 2005;15(4):281-307.

19. Yang SF, Hoffman NE. Ethylene biosynthesis and its regulation in higher plants. Annu Rev Plant Physiol. 1984;35(1):155-89.

20. Matilla AJ, Matilla-Vázquez MA. Involvement of ethylene in seed physiology. Plant Sci. 2008;175(1-2):87-97.

21. Booker MA, DeLong A. Producing the ethylene signal: regulation and diversification of ethylene biosynthetic enzymes. Plant Physiol. 2015;169(1):42-50.

22. Ruduś I, Sasiak M, Kępczyński J. Regulation of ethylene biosynthesis at the level of 1-aminocyclopropane-1-carboxylate oxidase (ACO) gene. Acta Physiol Plantarum. 2013:35(2):295-307.

23. Iglesias-Fernández R, Matilla A. After-ripening alters the gene expression pattern of oxidases involved in the ethylene and gibberellin pathways during early imbibition of Sisymbrium officinale L. seeds. J Exp Bot. 2009;60(6):1645-61.

24. Narsai R, Law SR, Carrie C, Xu L, Whelan J. In-depth temporal transcriptome profiling reveals a crucial developmental switch with roles for RNA processing and organelle metabolism that are essential for germination in Arabidopsis. Plant Physiol. 2011;157(3):1342-62.

25. Linkies A, Leubner-Metzger G. Beyond gibberellins and abscisic acid: how ethylene and jasmonates control seed germination. Plant Cell Rep. 2012; 31(2):253-70.

26. Calvo AP, Nicolás C, Lorenzo O, Nicolás G, Rodríguez D. Evidence for positive regulation by gibberellins and ethylene of ACC oxidase expression and activity during transition from dormancy to germination in Fagus sylvatica L. seeds. J Plant Growth Reg. 2004;23(1):44-53.

27. Chitnis VR, Gao F, Yao Z, Jordan MC, Park S, Ayele BT. After-ripening induced transcriptional changes of hormonal genes in wheat seeds: the cases of brassinosteroids, ethylene, cytokinin and salicylic acid. PLoS One. 2014;9(1):e87543.

28. Hendricks SB, Taylorson RB. Promotion of seed germination by nitrate, nitrite, hydroxylamine, and ammonium salts. Plant Physiol. 1974;54(3):304-9.

29. El-Maarouf-Bouteau H, Bailly C. Oxidative signaling in seed germination and dormancy. Plant Signal Behav. 2008;3(3):175-82

30. Whitaker C, Beckett RP, Minibayeva FV, Kranner I. Alleviation of dormancy by reactive oxygen species in Bidens pilosa L. seeds. South African J Bot. 2010; 76(3):601-5

31. Bailly C, El-Maarouf-Bouteau $\mathrm{H}$, Corbineau F. From intracellular signaling networks to cell death: the dual role of reactive oxygen species in seed physiology. Comptes Rendus Biol. 2008;331(10):806-14.

32. Oracz K, Bouteau HE, Farrant JM, Cooper K, Belghazi M, Job C, Job D, Corbineau F, Bailly $C$. ROS production and protein oxidation as a novel mechanism for seed dormancy alleviation. Plant J. 2007;50(3):452-65. 
33. Diaz-Vivancos P, Barba-Espín G, Hernández JA. Elucidating hormonal/ROS networks during seed germination: insights and perspectives. Plant Cell Rep. 2013;32(10):1491-502.

34. Noctor $\mathrm{G}$, Foyer $\mathrm{CH}$. Ascorbate and glutathione: keeping active oxygen under control. Annu Rev of Plant Biol. 1998;49(1):249-79.

35. Cembrowska-Lech D, Kępczyński J. Gibberellin-like effects of KAR 1 on dormancy release of Avena fatua caryopses include participation of nonenzymatic antioxidants and cell cycle activation in embryos. Planta. 2016; 243(2):531-48

36. Cadman CS, Toorop PE, Hilhorst HW, Finch-Savage WE. Gene expression profiles of Arabidopsis cvi seeds during dormancy cycling indicate a common underlying dormancy control mechanism. Plant J. 2006;46(5):805-22.

37. Finch-Savage WE, Leubner-Metzger G. Seed dormancy and the control of germination. New Phytol. 2006;171(3):501-23.

38. Hilhorst HW. Definitions and hypotheses of seed dormancy. Annu Plant Rev Online. 2007;27:50-71. https://doi.org/10.1002/9780470988848.ch3.

39. Awan S, Footitt S, Finch-Savage WE. Interaction of maternal environment and allelic differences in seed vigour genes determines seed performance in Brassica oleracea. Plant J. 2018;94(6):1098-108.

40. Hu J, Sadowski J, Osborn TC, Landry BS, Quiros CF. Linkage group alignment from four independent Brassica oleracea RFLP maps. Genome. 1998;41(2): 226-35

41. Momoh EJ, Zhou WJ, Kristiansson B. Variation in the development of secondary dormancy in oilseed rape genotypes under conditions of stress. Weed Res. 2002:42(6):446-55.

42. Gulden RH, Chiwocha S, Abrams S, McGregor I, Kermode A, Shirtliffe S. Response to abscisic acid application and hormone profiles in spring Brassica napus seed in relation to secondary dormancy. Canadian J Bot. 2004:82(11):1618-24

43. Lan TH, DelMonte TA, Reischmann KP, Hyman J, Kowalski SP, McFerson J, Kresovich S, Paterson AH. An EST-enriched comparative map of Brassica oleracea and Arabidopsis thaliana. Genome Res. 2000;10(6):776-88.

44. Kępczyński J, Van Staden J. Interaction of karrikinolide and ethylene in controlling germination of dormant Avena fatua L. caryopses. Plant Growth Reg. 2012;67(2):185-90

45. Simontacchi M, Jasid S, Puntarulo S. Nitric oxide generation during early germination of sorghum seeds. Plant Sci. 2004;167(4):839-47.

46. Kranner I, Roach T, Beckett RP, Whitaker C, Minibayeva FV. Extracellular production of reactive oxygen species during seed germination and early seedling growth in Pisum sativum. J Plant Physiol. 2010;167(10):805-11.

47. Oracz K, El-Maarouf-Bouteau H, Kranner I, Bogatek R, Corbineau F, Bailly C. The mechanisms involved in seed dormancy alleviation by hydrogen cyanide unravel the role of reactive oxygen species as key factors of cellular signaling during germination. Plant Physiol. 2009;150(1):494-505.

48. Shakeel SN, Wang X, Binder BM, Schaller GE. Mechanisms of signal transduction by ethylene: overlapping and non-overlapping signalling roles in a receptor family. AoB Plants. 2013;5:plt010. https://doi.org/10.1093/ aobpla/plt010

49. Ruduś I, Kępczyński J. Reference gene selection for molecular studies of dormancy in wild oat (Avena fatua L.) caryopses by RT-qPCR method. PloS One. 2018;13(2):e0192343.

50. Alscher RG, Erturk N, Heath LS. Role of superoxide dismutases (SODs) in controlling oxidative stress in plants. J Exp Bot. 2002;53(372):1331-41.

51. Fath $A$, Bethke PC, Jones RL. Enzymes that scavenge reactive oxygen species are down-regulated prior to gibberellic acid-induced programmed cell death in barley aleurone. Plant Physiol. 2001;126(1):156-66.

52. Cembrowska-Lech D, Koprowski M, Kępczyński J. Germination induction of dormant Avena fatua caryopses by KAR1 and GA3 involving the control of reactive oxygen species $\left(\mathrm{H}_{2} \mathrm{O}_{2}\right.$ and $\left.\mathrm{O}_{2}^{-}\right)$and enzymatic antioxidants (superoxide dismutase and catalase) both in the embryo and the aleurone layers. J Plant Physiol. 2015;176:169-79.

53. Feurtado JA, Kermode AR. A merging of paths: abscisic acid and hormonal cross-talk in the control of seed dormancy maintenance and alleviation. Annu Plant Rev Online. 2018;27:176-223. https://doi.org/10.1002/ 9781119312994.apr0282.

54. Sisler EC, Serek M. Compounds interacting with the ethylene receptor in plants. Plant Biol. 2003;5(05):473-80

55. Locke JM, Bryce $\mathrm{JH}$, Morris PC. Contrasting effects of ethylene perception and biosynthesis inhibitors on germination and seedling growth of barley (Hordeum vulgare L.). J Exp Bot. 2000;51(352):1843-9.
56. Oracz K, El-Maarouf-Bouteau H, Bogatek R, Corbineau F, Bailly C. Release of sunflower seed dormancy by cyanide: cross-talk with ethylene signalling pathway. J Exp Bot. 2008;59(8):2241-51.

57. Petruzzelli L, Coraggio I, Leubner-Metzger G. Ethylene promotes ethylene biosynthesis during pea seed germination by positive feedback regulation of 1 aminocyclo-propane-1-carboxylic acid oxidase. Planta. 2000;211(1):144-9.

58. Schierle J, Rohwer F, Bopp M. Distribution of ethylene synthesis along the etiolated pea shoot and its regulation by ethylene. J Plant Physiol. 1989; 134(3):331-7.

59. Gallie DR. Ethylene receptors in plants-why so much complexity? F1000Prime Rep. 2015;7:39. https://doi.org/10.12703/P7-39.

60. Gallie DR. Regulated ethylene insensitivity through the inducible expression of the Arabidopsis etr1-1 mutant ethylene receptor in tomato. Plant Physiol. 2010;152(4):1928-39.

61. Dobrzyn'ska U, Zielin'ska K, Gniazdowska A, Bogatek R. Involvement of antioxidant system in HCN and NO- mediated dormancy removal of apple embryo. Polish J Nat Sci. 2008;5(Suppl):164.

62. Dębska K, Krasuska U, Budnicka K, Bogatek R, Gniazdowska A. Dormancy removal of apple seeds by cold stratification is associated with fluctuation in $\mathrm{H}_{2} \mathrm{O}_{2}, \mathrm{NO}$ production and protein carbonylation level. J Plant Physiol. 2013;170(5):480-8.

63. Nagase R, Katayama M, Mura H, Matsuo N, Tanabe $Y$. Synthesis of the seed germination stimulant 3-methyl-2H-furo $[2,3-c]$ pyran-2-ones utilizing direct and regioselective Ti-crossed aldol addition. Tetrahedron Lett. 2008;49(2930):4509-12.

64. Velikova V, Yordanov I, Edreva A. Oxidative stress and some antioxidant systems in acid rain-treated bean plants: protective role of exogenous polyamines. Plant Sci. 2000;151(1):59-66.

65. Nguyen HM, Sako K, Matsui A, Suzuki Y, Mostofa MG, Ha CV, Tanaka M, Tran LS, Habu Y, Seki M. Ethanol enhances high-salinity stress tolerance by detoxifying reactive oxygen species in Arabidopsis thaliana and rice. Frontiers Plant Sci. 2017:8:1001.

66. Elstner EF, Heupel A. Inhibition of nitrite formation from hydroxylammoniumchloride: a simple assay for superoxide dismutase. Anal Biochem. 1976;70(2):616-20.

67. Misra HP, Fridovich I. The role of superoxide anion in the autoxidation of epinephrine and a simple assay for superoxide dismutase. J Bio Chem. 1972; 247(10):3170-5

68. Aebi H. Catalase in vitro. In: Methods in enzymology, vol. 105. Europe PMC: Academic Press; 1984. p. 121-6. http://dx.doi.org/10.1016/S0076-68.

69. Esterbauer $H$, Grill D. Seasonal variation of glutathione and glutathione reductase in needles of Picea abies. Plant Physiol. 1978;61(1):119-21.

70. Bradford MM. A rapid and sensitive method for the quantitation of microgram quantities of protein utilizing the principle of protein-dye binding. Anal Biochem. 1976;72(1-2):248-54.

71. Shuai H, Meng Y, Luo X, Chen F, Zhou W, Dai Y, Qi Y, Du J, Yang F, Liu J, Yang W. Exogenous auxin represses soybean seed germination through decreasing the gibberellin/abscisic acid (GA/ABA) ratio. Sci Rep. 2017;7(1):12620

72. Concepcion M, Lizada C, Yang SF. A simple and sensitive assay for 1aminocyclopropane-1-carboxylic acid. Anal Biochem. 1979;100(1):140-5.

73. Yip WK, Dong JG, Yang SF. Purification and characterization of 1aminocyclopropane-1-carboxylate synthase from apple fruits. Plant Physiol. 1991;95(1):251-7.

74. Mathooko FM, Kubo Y, Inaba A, Nakamura R. Partial characterization of 1aminocyclopropane-1-carboxylate oxidase from excised mesocarp tissue of winter squash fruit. Sci Rep Faculty Agri Okayama Univ. 1993;82(1):49-59.

\section{Publisher's Note}

Springer Nature remains neutral with regard to jurisdictional claims in published maps and institutional affiliations. 